\title{
ACCUMULATION OF SELENIUM IN RYE PLANTS (SECALE CEREALE L.) AT DIFFERENT STAGES OF DEVELOPMENT AND GRAIN QUALITY DUE TO SELENATE SOIL SUPPLEMENTATION
}

\author{
SKRYPNIK, L. N. ${ }^{*}$ - KURKOVA, T. N. - ChUPAKHINA, G. N. \\ School of Life Sciences, Immanuel Kant Baltic Federal University \\ Universitetskaya str., 2, 236040 Kaliningrad, Russia \\ (phone: +7-4012-595-595-5000) \\ *Corresponding author \\ e-mail: LSkrypnik@kantiana.ru
}

(Received 23 $3^{\text {rd }}$ May 2018; accepted $2^{\text {nd }}$ Jan 2019)

\begin{abstract}
The accumulation of selenium by rye at different stages of development depending on the dosages of selenium and $\mathrm{pH}$ of soil was investigated. The findings testify that in case of increased selenium content in the soil selenium concentration in the plant also increased. Moreover, it was revealed that in the process of vegetation total selenium content in the rye increases; however the intensity of selenium accumulation by plants decreases. The positive effect of low concentrations of selenium on biomass accumulation of rye plants was found. The total protein content in rye grain was higher by application of selenium. The results of this work show the possibilities of applying of the seleniferous fertilizers for the increasing in the content of micronutrient in the grain plants. The recommended optimal concentrations of selenium additive are $0.01-0.05 \mathrm{mg} \mathrm{kg}^{-1}$ of soil.
\end{abstract}

Keywords: cereals, seleniferous fertilizers, microelement, yield, proteins

\section{Introduction}

Rye (Secale cereale L.) is one of the most important cereals in middle, eastern, and especially north Europe. Among the cereals, rye can be grown under extreme climatic and poor soil conditions. On a global scale rye is a minor crop, its production being about 5\% that of wheat or rice (Korzun et al., 2001). However, recently, interest in this crop has increased because of its dietary value. Rye is especially rich source of phytochemicals such as phenolic acids, lignans, alkylresorcinols and benzoxazinoids (Pihlava et al., 2018).

So far scientists do not know for certain whether selenium is an essential microelement for growth and development of plants. Some researchers admit necessity of selenium for plants others believe that selenium is not an essential element for normal life history of vegetative organism. However, there are a number of facts confirming positive influence of selenium on various life processes. Thus, it has been established that selenium increases antioxidant potential and stress-resistance of plants, stimulates their growth in the conditions of oxidation stress caused by UV-radiation (Hartikainen and Xue, 1999; Xue and Hartikainen, 2000; Pennenen et al., 2002; Germ et al., 2007; Golob et al., 2018), herbicides, hypothermia (Seppaenen et al., 2003; Xu et al., 2003), drought stress (Nawaz et al., 2015a; Aissa et al., 2018), plant's ageing (Xue et al., 2001; Djanaguiraman et al., 2004, 2005), salt stress (Kong et al., 2005; Diao et al., 2014; Jiang et al., 2017). There has been noted increase of yield level of some plants further to application of low concentrations of selenium (Graham et al., 2005; Thavarajah et al., 2015; Nawaz et al., 2015b). Positive effect of selenium is also 
revealed in increased germinating capacity and improved survival potential of plantlets in stress conditions (hypo- and hyperthermia, hypoxia, soil salinity and acidulation etc.) In the presence of selenium lipid membrane peroxidation processes in conditions of high light intensity and low temperatures are reduced, testifying to the effect that selenium has an influence on oxidation-reduction cell status (Zhu et al., 2009).

Selenium intake by plants from soil depends on many factors, for instance, on soil $\mathrm{pH}$, humus content, chemical form of selenium (Zhao et al., 2005; Hawrylak-Nowak et al., 2015). Other important factor able to influence selenium quantity in plants is plant species. There are certain selenium accumulating plants, which accumulate from 100 to several thousand $\mathrm{mg}$ Se per $\mathrm{kg}$ of dry substance, in other plants including cereals selenium content is $0.01-1.00 \mathrm{mg} \mathrm{kg}^{-1}$ on the average (Terry et al., 2000; Wangeline et al., 2011; Pilon-Smits, 2017). Lyons et al. (2005) showed that the main reason for variability in the content of selenium in some cereals (wheat, barley, rye) is the selenium concentration in the soil, but not genotypic variation. Similar findings were also obtained in studies with three varieties of wheat (Sharma et al., 2015).

Analysis of selenium accumulation pattern is very important both for study of biochemical role of this microelement for plants and to study application potential of selenium-containing fertilizers in order to increase selenium supply of animals and humans.

Purpose of this paper was to study selenium accumulation by rye (Secale cereale L.) at various ontogenesis stages subject to application of selenium additive to the soil and the impact of this on the yield and grain quality.

\section{Materials and methods}

\section{Plant cultivation}

The pot experiment was conducted in Kaliningrad, Russia (54 $43^{\prime} \mathrm{N}, 20^{\circ} 30^{\prime} \mathrm{E}$ ), from 12 April till 17 July, 2015, in a glass covered greenhouse of the Institute for Chemistry and Biology at Immanuel Kant Baltic Federal University. The greenhouse was not heated and we followed the natural light cycle, no additional lighting was supplied. Common rye (Secale cereale L.) cv. Pukhovchanka was used for experiments. The rye was grown in culture pots in permanent-set soil having $\mathrm{pH} 5.4$ and $\mathrm{pH}$ 6.6. The dimension of pot was $29 \times 20 \mathrm{~cm}$ (height $\times$ radius) and each pot contained $10 \mathrm{~kg}$ of soil. Selenium was applied in the soil in the form of a sodium selenate solution $\left(\mathrm{Na}_{2} \mathrm{SeO}_{4}\right)$ in concentrations $0.01 \mathrm{mg}, 0.05 \mathrm{mg}, 0.1 \mathrm{mg}, 0.5 \mathrm{mg}$ (in terms of $1 \mathrm{~kg}$ of the soil). Selenium effect on the plants was compared to control treatment (without selenium supplementation). Initial selenium content in the soil was $0.084 \mathrm{mg} / \mathrm{kg}$. Moreover, following basic fertilizers were applied: $0.17 \mathrm{~g}$ of nitrogen in terms of ammonium nitrate, $0.13 \mathrm{~g}$ of $\mathrm{P}_{2} \mathrm{O}_{5}$ in terms of potassium hydrophosphate, $0.28 \mathrm{~g}$ of $\mathrm{K}_{2} \mathrm{O}$ in terms of potassium hydrophosphate and sulfate and $0.044 \mathrm{of} \mathrm{MgO}$ in terms of magnesium sulfate per kg of the soil. Solutions of fertilizers and sodium selenate were applied in such manner so that they cannot mix with each other. First in extreme points of soil surface square basic microelements were applied, whereas sodium selenate was applied in the central point. After the soil dried out it was mixed and the rye was planted. Into each pot were planted 20 plants. During experiments the plants were watered with distilled water.

The analysis of plant were performed at three plant growth stages (GS): at tillering stage (GS 26, main shoot and 6 tillers), booting stage (GS 45, mid-boot stage: boots just 
visibly swollen) and milk development stage (GS 75, medium milk) according to Zadoks' scale (Zadoks et al., 1974).

Four replications for each treatment (selenium suplements, soil $\mathrm{pH}$, and stage of development) were condacted. There were 120 pots in total.

\section{Plant analysis}

Selenium was determined by atomic absorption spectrometry (Unicam M Series, Software Solaar, Thermo Scientific) with mineralization of vegetative samples through autoclave decomposition under pressure (Kurkova et al., 2008).

The extraction of reserve proteins was performed by deionized water (for albumin), $5 \% \mathrm{NaCl}$ (for globulin), 60\% ethanol (for prolamin), and $0.4 \% \mathrm{NaOH}$ (for glutelin). Protein concentration was determined according to Bradford, using BSA as the standard (Bradford, 1976).

\section{Statistical analysis}

Statistical analysis was performed using the SigmaPlot 12.3 (Systat Software GmbH, Erkrath, Germany). The mean of four independent samples were taken to represent the result of each replicate. The results were reported as mean \pm standard deviation (SD). To identify the difference in means the one-factorial ANOVA was conducted for each factor (selenium application, growth stage, $\mathrm{pH}$ of soil, organs of plant) separately Difference among means were determined by Tukey's test at a significance level of $p \leq 0.05$.

\section{Results}

\section{Accumulation of selenium in rye at different stages of development}

In order to study selenium accumulation by the rye the plants were grown in the soil enriched with this microelement in concentrations $0.01-0.5 \mathrm{mg} \mathrm{Se} \mathrm{kg}{ }^{-1}$ of soil. Findings on selenium content in vegetative specimen were compared to the plant without selenium supplementation. Initial selenium content in the soil was $0.084 \mathrm{mg} \mathrm{kg}^{-1}$. Selenium was identified in above-ground part of the plant at three stages of vegetation. Results of study of relation between selenium content in all plant and quantity of selenium applied in the soil at different stages of the plant ontogenesis are shown in Figure 1.

The findings testify that in case of increased selenium content in the soil selenium concentration in the plant also increased. Thus, after application of $0.05 \mathrm{mg}$ of selenium per $\mathrm{kg}$ of soil, $4.74 \pm 0.06 \mu \mathrm{g}$ of selenium was identified in the plant (at milk development stage), while after application of $0.5 \mathrm{mg}$ of selenium per $\mathrm{kg}$ of soil selenium content in the plant was almost 16 times higher $-74 \pm 2 \mu \mathrm{g}$. Moreover, it was revealed that in the process of vegetation total selenium content in the rye increases, however as it is obvious on the picture intensity of selenium accumulation by plants decreases.

In order to study intensity of selenium accumulation by the rye at different ontogenesis stages total selenium content in the plant was calculated per gram of vegetating mass. Dependence of selenium concentration in the plant on selenium concentration in the soil is illustrated in Figure 2. 
The study shows that tillering stage was characterized by maximum selenium concentration, as the plant advanced intensity of its accumulation progressively decreased. Maximum selenium concentration in the rye at tillering stage was $59.3 \pm 0.4 \mu \mathrm{g} \mathrm{g}^{-1}$, at booting stage $-31.7 \pm 0.3 \mu \mathrm{g} \mathrm{g}^{-1}$ and at milk development stage only $11.8 \pm 0.3 \mu \mathrm{g} \mathrm{g}^{-1}$.

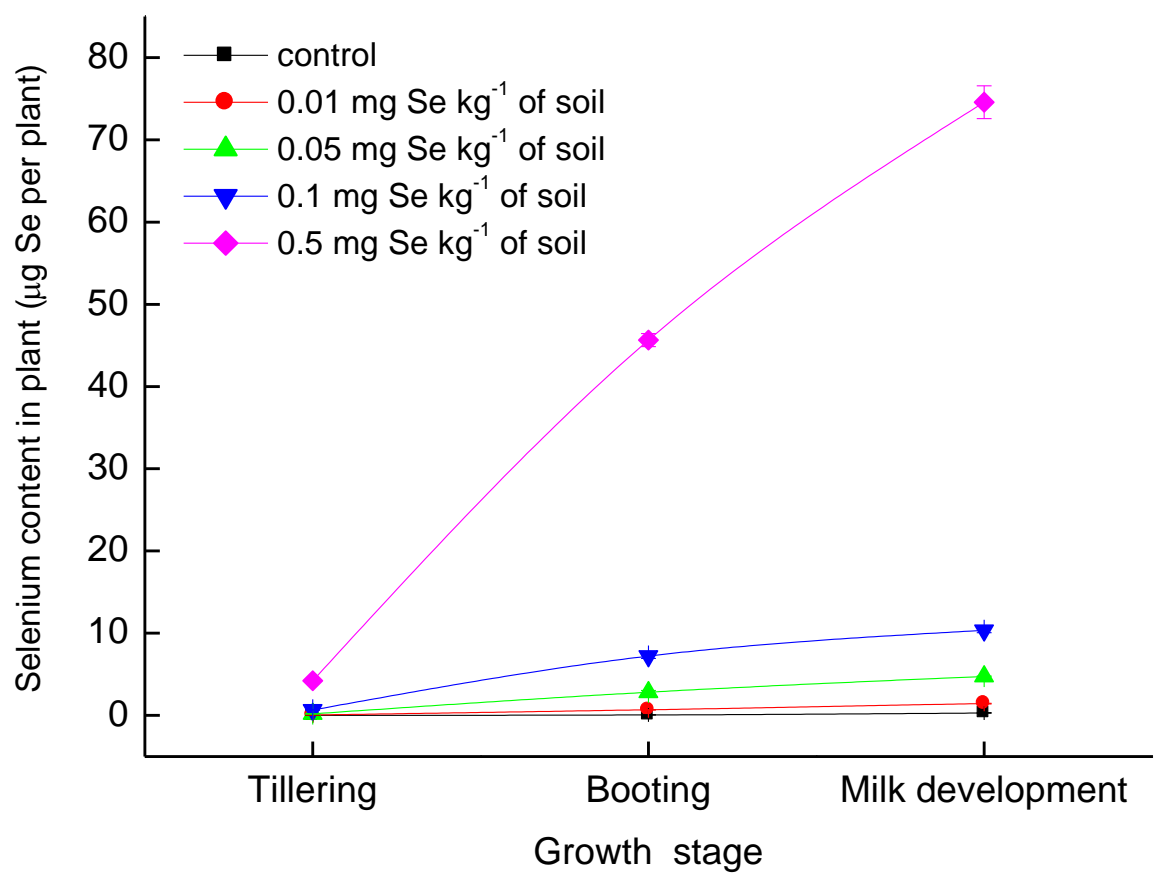

Figure 1. Selenium content in rye plants at different stages of ontogenesis in depending on the amount of selenium supplements (soil pH 6.6)

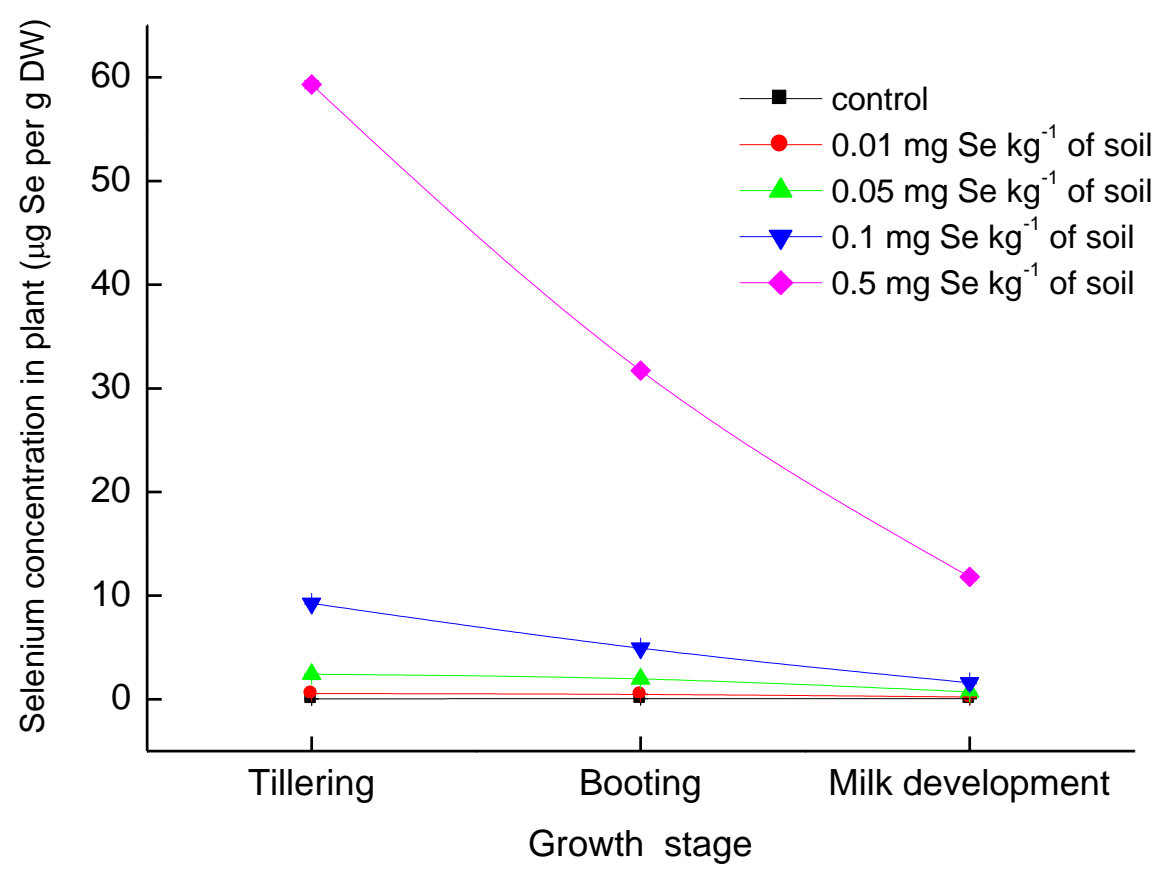

Figure 2. Selenium concentration in rye plants at different stages of ontogenesis in depending on the amount of selenium supplements (soil pH 6.6) 


\section{Influence of soil pH on the selenium accumulation in rye}

As seen from the provided data, soil acidity difference being investigated influenced selenium intake by the plant. And considerable difference was obvious for the plants grown in the soil enriched with this microelement (Table 1). The significant higher concentration of selenium in rye plant growing on less acidic soil $(\mathrm{pH}$ 6.6) was determined. However, at tillering stage in plant growing on soil with $\mathrm{pH} 5.4$ and without selenium supplementation the concentration of selenium was higher. At the later stages of plant development (booting and milk development), no significant difference in the selenium concentrations in plants growing on the soil with different acidity and without selenium additives was found.

At the same time, it was revealed that nature of selenium accumulation by the rye in the process of vegetation does not depend on the soil acidity: at the early stage of development - at tillering stage the microelement was received by the plant intensively, at the same time total selenium content in the plant increased.

Table 1. Selenium concentration in rye plants $\left(\mu g g^{-1}\right)$ in depending of soil acidity and selenium addition concentration

\begin{tabular}{|c|c|c|c|}
\hline $\begin{array}{c}\text { Stage of } \\
\text { ontogenesis }\end{array}$ & 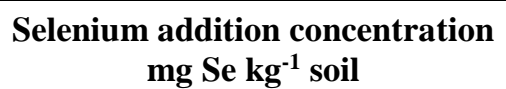 & pH 5.4 & pH 6.6 \\
\hline \multirow{5}{*}{ Tillering } & 0 & $0.042 \pm 0.002^{\mathrm{a}}$ & $0.031 \pm 0.002^{\mathrm{b}}$ \\
\hline & 0.01 & $0.58 \pm 0.03^{\mathrm{a}}$ & $0.55 \pm 0.02^{\mathrm{a}}$ \\
\hline & 0.05 & $2.2 \pm 0.1^{\mathrm{b}}$ & $2.41 \pm 0.07^{\mathrm{a}}$ \\
\hline & 0.1 & $7.4 \pm 0.1^{\mathrm{b}}$ & $9.24 \pm 0.08^{\mathrm{a}}$ \\
\hline & 0.5 & $56.8 \pm 0.7^{\mathrm{b}}$ & $59.3 \pm 0.4^{\mathrm{a}}$ \\
\hline \multirow{5}{*}{ Booting } & 0 & $0.048 \pm 0.004^{\mathrm{a}}$ & $0.051 \pm 0.003^{\mathrm{a}}$ \\
\hline & 0.01 & $0.42 \pm 0.01^{\mathrm{b}}$ & $0.47 \pm 0.03^{\mathrm{a}}$ \\
\hline & 0.05 & $1.81 \pm 0.04^{\mathrm{b}}$ & $1.97 \pm 0.04^{\mathrm{a}}$ \\
\hline & 0.1 & $4.38 \pm 0.05^{\mathrm{b}}$ & $4.94 \pm 0.08^{\mathrm{a}}$ \\
\hline & 0.5 & $24.9 \pm 0.1^{\mathrm{b}}$ & $31.7 \pm 0.3^{\mathrm{a}}$ \\
\hline \multirow{5}{*}{ Milk development } & 0 & $0.046 \pm 0.002^{\mathrm{a}}$ & $0.047 \pm 0.001^{\mathrm{a}}$ \\
\hline & 0.01 & $0.167 \pm 0.005^{\mathrm{b}}$ & $0.212 \pm 0.004^{\mathrm{a}}$ \\
\hline & 0.05 & $0.65 \pm 0.02^{\mathrm{b}}$ & $0.71 \pm 0.01^{\mathrm{a}}$ \\
\hline & 0.1 & $1.42 \pm 0.07^{\mathrm{b}}$ & $1.6 \pm 0.1^{\mathrm{a}}$ \\
\hline & 0.5 & $10.4 \pm 0.6^{b}$ & $11.8 \pm 0.3^{\mathrm{a}}$ \\
\hline
\end{tabular}

Means within rows followed by different lower-case letters stand for significance different at $p \leq 0.05$

\section{Selenium distribution in different organs of the rye plant}

Study of selenium distribution in different organs of the rye plant testified that selenium content in the grain was higher than in the stem (Table 2). It was particularly evident in case of low selenium content in the soil; in case of higher selenium additives in the soil difference between its content in the stem and in the ear became not so evident. Thus, there was no significant difference between the content of selenium in the stem and grain of plants grown with the addition $0.05 \mathrm{mg}$ selenium per $\mathrm{kg}$ soil and by soil acidity of 5.4 . 
Table 2. Selenium content in grain and stem ( $\mu g$ per plant) of rye plants depending on selenium supplements concentration and $\mathrm{pH}$ of the soil

\begin{tabular}{c|c|c|c}
\hline Soil pH & $\begin{array}{c}\text { Selenium addition concentration } \\
\text { mg Se kg-1 }^{-1} \text { soil }\end{array}$ & Grain & Stem \\
\hline \multirow{5}{*}{5.4} & 0 & $0.21 \pm 0.01^{\mathrm{a}}$ & $0.12 \pm 0.01^{\mathrm{b}}$ \\
& 0.01 & $0.75 \pm 0.08^{\mathrm{a}}$ & $0.42 \pm 0.04^{\mathrm{b}}$ \\
& 0.05 & $2.7 \pm 0.1^{\mathrm{a}}$ & $1.59 \pm 0.09^{\mathrm{b}}$ \\
& 0.1 & $6.4 \pm 0.5^{\mathrm{a}}$ & $3.4 \pm 0.5^{\mathrm{b}}$ \\
& 0.5 & $35.4 \pm 1.3^{\mathrm{a}}$ & $33.1 \pm 1.7^{\mathrm{a}}$ \\
\hline \multirow{5}{*}{6.6} & 0 & $0.18 \pm 0.04^{\mathrm{a}}$ & $0.11 \pm 0.01^{\mathrm{b}}$ \\
& 0.01 & $0.82 \pm 0.05^{\mathrm{a}}$ & $0.52 \pm 0.03^{\mathrm{b}}$ \\
& 0.05 & $2.93 \pm 0.03^{\mathrm{a}}$ & $1.75 \pm 0.04^{\mathrm{b}}$ \\
& 0.1 & $6.1 \pm 0.2^{\mathrm{a}}$ & $4.5 \pm 0.2^{\mathrm{b}}$ \\
& 0.5 & $38.3 \pm 1.2^{\mathrm{a}}$ & $35.1 \pm 0.6^{\mathrm{b}}$ \\
\hline
\end{tabular}

Means within rows followed by different lower-case letters stand for significance different at $p \leq 0.05$

\section{Effect of soil applied selenium concentration on biomass accumulation of rye}

This paper studies effect of applied selenium soil addition on accumulation of biomass by the rye plants at various ontogenesis stages (Table 3). The findings show that optimal for the rye plant is selenium additive in concentration of $0.01-0.05 \mathrm{mg} \mathrm{kg}^{-1}$ of soil (soil pH is 6.6). Under these conditions at all stages of development the plants built up maximum biomass both compared to the reference specimen and to the specimen with higher selenium concentrations. At booting stage positive effect of selenium additive in the form of sodium selenate was fixed for all plants irrespective of concentration of selenium applied in the soil. In the case of soil pH 5.4 selenium effect on the plant was more toxic. Positive effect was fixed at tillering stage after application of $0.01 \mathrm{mg} \mathrm{Se} \mathrm{kg}^{-1}$ of soil and at booting stage after application of $0.05-0.1 \mathrm{mg}$ Se per $\mathrm{kg}$ of soil, whereas at milk development stage selenium effect was purely toxic irrespective of concentration.

Table 3. Influence of selenium concentration in soil on the biomass $(g)$ of rye plants at different ontogenesis stages

\begin{tabular}{c|c|c|c|c|c|c}
\hline \multirow{2}{*}{$\begin{array}{c}\text { Stage of } \\
\text { ontogenesis }\end{array}$} & \multirow{2}{*}{$\begin{array}{c}\text { Soil } \\
\mathbf{p H}\end{array}$} & \multicolumn{5}{|c}{ Selenium addition concentration, mg Se kg $\mathbf{~}^{-1}$ soil } \\
\cline { 3 - 7 } & $\mathbf{0}$ & $\mathbf{0 . 0 1}$ & $\mathbf{0 . 0 5}$ & $\mathbf{0 . 1}$ & $\mathbf{0 . 5}$ \\
\hline \multirow{2}{*}{ Tillering } & 5.4 & $0.074 \pm 0.004^{\mathrm{a}}$ & $0.081 \pm 0.002^{\mathrm{a}}$ & $0.075 \pm 0.004^{\mathrm{a}}$ & $0.077 \pm 0.005^{\mathrm{a}}$ & $0.073 \pm 0.004^{\mathrm{a}}$ \\
& 6.6 & $0.072 \pm 0.005^{\mathrm{b}}$ & $0.083 \pm 0.005^{\mathrm{a}}$ & $0.078 \pm 0.003^{\mathrm{ab}}$ & $0.072 \pm 0.001^{\mathrm{b}}$ & $0.071 \pm 0.001^{\mathrm{b}}$ \\
\hline \multirow{2}{*}{ Booting } & 5.4 & $1.39 \pm 0.024^{\mathrm{b}}$ & $1.42 \pm 0.016^{\mathrm{b}}$ & $1.47 \pm 0.018^{\mathrm{a}}$ & $1.48 \pm 0.024^{\mathrm{a}}$ & $1.38 \pm 0.020^{\mathrm{b}}$ \\
& 6.6 & $1.22 \pm 0.038^{\mathrm{b}}$ & $1.44 \pm 0.031^{\mathrm{a}}$ & $1.43 \pm 0.018^{\mathrm{a}}$ & $1.46 \pm 0.046^{\mathrm{a}}$ & $1.44 \pm 0.036^{\mathrm{a}}$ \\
\hline Milk & 5.4 & $6.73 \pm 0.029^{\mathrm{a}}$ & $6.54 \pm 0.049^{\mathrm{b}}$ & $6.42 \pm 0.065^{\mathrm{c}}$ & $6.28 \pm 0.057^{\mathrm{d}}$ & $6.24 \pm 0.048^{\mathrm{d}}$ \\
development & 6.6 & $6.41 \pm 0.080^{\mathrm{bc}}$ & $6.79 \pm 0.047^{\mathrm{a}}$ & $6.68 \pm 0.069^{\mathrm{a}}$ & $6.47 \pm 0.049^{\mathrm{b}}$ & $6.32 \pm 0.022^{\mathrm{c}}$ \\
\hline
\end{tabular}

Means within rows followed by different lower-case letters stand for significance different at $p \leq 0.05$

Moreover, we studied selenium effect on accumulation of biomass separately by the ear and stem of the rye (Table 4). Application of lower concentrations of selenium at 
soil $\mathrm{pH} 6.6$ promoted increase of biomass both of the stem and of the ear. At this, for the ear stimulating effect of selenium was fixed for all its concentrations, while maximum ear mass was fixed after application of $0.05 \mathrm{mg} \mathrm{Se} \mathrm{kg}^{-1}$ of soil. In more acid soil we revealed mass decrease both for the ear and the stem after enriching the soil with selenium.

Table 4. Influence of selenium concentration in soil on the biomass $(g)$ of different organs of rye plants at milk development stage

\begin{tabular}{c|c|c|c|c|c|c}
\hline \multirow{2}{*}{ Plant part } & \multirow{2}{*}{$\begin{array}{c}\text { Soil } \\
\mathbf{p H}\end{array}$} & \multicolumn{5}{|c}{ Selenium addition concentration, mg Se kg-1 soil } \\
\cline { 3 - 7 } & & $\mathbf{0}$ & $\mathbf{0 . 0 1}$ & $\mathbf{0 . 0 5}$ & $\mathbf{0 . 1}$ & $\mathbf{0 . 5}$ \\
\hline \multirow{2}{*}{ Stem } & 5.4 & $2.67 \pm 0.042^{\mathrm{a}}$ & $2.61 \pm 0.044^{\mathrm{ac}}$ & $2.63 \pm 0.023^{\mathrm{ab}}$ & $2.54 \pm 0.031^{\mathrm{c}}$ & $2.59 \pm 0.031^{\mathrm{bc}}$ \\
& 6.6 & $2.62 \pm 0.034^{\mathrm{b}}$ & $2.84 \pm 0.041^{\mathrm{a}}$ & $2.54 \pm 0.030^{\mathrm{c}}$ & $2.53 \pm 0.022^{\mathrm{c}}$ & $2.41 \pm 0.021^{\mathrm{d}}$ \\
\hline \multirow{2}{*}{ Ear } & 5.4 & $4.02 \pm 0.030^{\mathrm{a}}$ & $3.90 \pm 0.030^{\mathrm{b}}$ & $3.83 \pm 0.053^{\mathrm{bc}}$ & $3.75 \pm 0.065^{\mathrm{cd}}$ & $3.67 \pm 0.040^{\mathrm{d}}$ \\
& 6.6 & $3.79 \pm 0.049^{\mathrm{c}}$ & $3.96 \pm 0.039^{\mathrm{b}}$ & $4.14 \pm 0.044^{\mathrm{a}}$ & $3.87 \pm 0.052^{\mathrm{bc}}$ & $3.84 \pm 0.034^{\mathrm{c}}$ \\
\hline
\end{tabular}

Means within rows followed by different lower-case letters stand for significance different at $p \leq 0.5$

\section{Influence of selenium on quantitative composition of reserve protein fractions in rye}

Quantitative composition of reserve protein fractions was depending on selenium supply concentration to the soil (Table 5). The total protein content was higher by application of selenium. However, only the contents of globulin and glutelin in the rye grains increased with increasing Se fertilization. For albumin maximum of content was shown for low selenium concentrations (control and $0.01 \mathrm{mg} \mathrm{kg}^{-1}$ ). Prolamin concentrations were not affected by selenium concentration in soil.

Table 5. Influence of selenium in soil ( $p H$ 6.6) on quantitative composition of protein fractions in the grain of rye plants

\begin{tabular}{c|c|c|c|c|c}
\hline \multirow{2}{*}{$\begin{array}{c}\text { Selenium addition } \\
\text { concentration, mg Se kg-1 }\end{array}$} & \multirow{2}{*}{$\begin{array}{c}\text { Total poil } \\
\text { content, \% }\end{array}$} & Albumins & Globulins & Prolamins & Glutelins \\
\cline { 3 - 6 } & $12.4 \pm 0.4^{\mathrm{b}}$ & $24.7 \pm 0.7^{\mathrm{ab}}$ & $19.2 \pm 0.2^{\mathrm{d}}$ & $25.4 \pm 0.4^{\mathrm{a}}$ & $16.5 \pm 0.2^{\mathrm{d}}$ \\
0.01 & $13.9 \pm 0.6^{\mathrm{a}}$ & $25.3 \pm 0.4^{\mathrm{a}}$ & $19.8 \pm 0.6^{\mathrm{d}}$ & $24.7 \pm 0.7^{\mathrm{ab}}$ & $17.8 \pm 0.6^{\mathrm{c}}$ \\
0.05 & $14.3 \pm 0.3^{\mathrm{a}}$ & $23.9 \pm 0.9^{\mathrm{b}}$ & $21.6 \pm 0.6^{\mathrm{c}}$ & $25.1 \pm 0.8^{\mathrm{a}}$ & $18.2 \pm 0.4^{\mathrm{c}}$ \\
0.1 & $13.8 \pm 0.3^{\mathrm{a}}$ & $21.8 \pm 0.6^{\mathrm{c}}$ & $23.4 \pm 0.4^{\mathrm{b}}$ & $23.4 \pm 0.6^{\mathrm{b}}$ & $19.7 \pm 0.8^{\mathrm{b}}$ \\
0.5 & $13.6 \pm 0.5^{\mathrm{a}}$ & $20.1 \pm 0.4^{\mathrm{d}}$ & $25.9 \pm 0.8^{\mathrm{a}}$ & $24.2 \pm 0.9^{\mathrm{ab}}$ & $23.4 \pm 0.7^{\mathrm{a}}$ \\
\hline
\end{tabular}

Means within rows followed by different lower-case letters stand for significance different at $p \leq 0.05$

\section{Discussion}

The study of selenium accumulation by the rye plants at different growth stages in depending on selenium soil application in concentrations $0.01-0.5 \mathrm{mg} \mathrm{Se} \mathrm{kg}^{-1}$ was conducted. There are four main methods for selenium application to plants: (1) adding Se to the soil; (2) foliar or fruit spraying; (3) soaking seeds in a Se solution before sowing; and (4) hydroponic cultivation with a nutrient solution containing Se (Puccinelli et al., 2017). The first two methods are most widely used due to their efficient and convenient. Despite a number of advantages of foliar processing, it is important to take into account the structural and chemical characteristics of the plant 
leaves. In the case of cereals, it is very difficult to produce true foliar processing, some fertilizer is deposited on the soil and extracted by the plant from there. In addition, the application of selenium into the soil before planting, allows us to estimate its accumulation into the plant at different stages of development.

The findings on selenium accumulation by the rye plants display in general the picture typical for cereals, when some elements (especially those participating in synthesis of labile organic compounds) are absorbed by plants at early ontogenesis stages with a rate exceeding dry substance accumulation. Later, after completion of tillering stage stem starts its intensive growth, which leads to sharp decrease of relative content of these elements in dry substance as a result of "dilution" effect.

The one reason of increased intensity of selenium accumulation by the rye in ontogenesis in the course of our experiment was probably exhaustion of the soil in the culture pot as a consequence of absorption of most part of selenium from the soil at initial stages of the plant development. However, as computation shows selenium content in the soil after tillering stage decreased by $1-2 \%$, while selenium concentration per gram of dry vegetating material decreased by $20 \%$. Therefore, the reason of decreased intensity of selenium accumulation by the plants in vegetation process could not be only soil exhaustion with this microelement.

High selenium content in vegetating material at tillering stage was probably associated first of all with physiological functions of selenium. At tillering stage metabolic processes in nurslings are active resulting in intensive generation peroxides of hydrogen and organic molecules, by-products of many biochemical reactions. Hypothetically selenium microelement in plants, same as in mammal organisms, is an essential component of antioxidant system contributing to cell protection against destructive effect of active forms of oxygen. Antioxidant action of selenium may be explained by its influence on activity of glutathione-peroxidase - ferment having foremost significance in protection of plant cell from continuously generated hydroperoxides (Durán et al., 2016; Wu et al., 2017). Thus, intensive selenium accumulation by rye plants at tillering stage testifies to important role of this microelement for normal growth of rye especially at early stages of the plant development.

Assimilation of selenium by the plant is influenced by the physicochemical factors of the soil, such as redox status, $\mathrm{pH}$ and microbiological activity (Mehdi et al., 2013). In the present study the rye plant growing on less acidity soil accumulated more selenium. Increase of selenium content in the plants grown in less acid soil can be explained, on the one hand, by the fact that in the soil of high acidity anionic adsorption increases therefore most part of selenium is in absorbed condition, on the other hand, in case of low soil $\mathrm{pH}$, hexavalent selenium is more prone to restorative process, and consequently in acid soil it is mostly in the form of selenite-ion which is not easily accessible for the plants. Lack of trustworthy difference in selenium intake by the plants depending on soil acidity in the case of small concentrations of the microelement is most probably conditioned by the fact that absorption and restorative processes insignificantly influence total pool of bioavailable selenium in the soil.

The study indicated that selenium predominantly accumulates in the grain, in comparison with the stem of rye. This result conforms to literary facts received earlier for winter wheat (Schulz et al., 1998). Selenium concentration in the grain was conditioned, most of all, by its physiological role in the plant, in particular, by selenium ability to substitute sulfur in most important amino acids (Sors et al., 2005; Reynolds et 
al., 2017; El Mehdawi, 2018). Moreover, predominant selenium accumulation in the ear may indirectly evidence necessity of this microelement. Such result is also of practical importance and should be taken into account when enriching cereals with selenium in order to increase selenium supply of animals and humans.

One of the peculiar features of selenium microelement is its dual nature, i.e. possible manifestation of both antioxidant and pro-oxidant features. Basic factor conditioning one or another selenium action is its concentration.

Positive effect of selenium on growth processes of the rye may be connected with its antioxidant features, i.e. ability to liquidate excessively accumulated free radicals. Thereupon excessive quantities of selenium, on the contrary, lead to intensification of generation processes of active oxygen forms. Some authors attribute positive effect of selenium on plant growth processes to its influence on hormonal status, in particular, under effect of sodium selenite increase of indoleacetic acid and decrease of abscisic acid were observed (Wang et al., 2018).

Negative effect of high concentrations of selenium on accumulation of biomass by the rye plants may also be attributed to substantial disturbance of the cell amino acid balance. Rye pertains to the plants of the 3rd group, i.e. plants not accumulating selenium, for which excessive substitution of cysteine or methionine in proteins by selenium-cysteine or selenium- methionine is particularly typical. At soil pH 5.4 selenium effect on the plant was more toxic. Toxic effect of selenium for the plants grown on more acid soil may be attributed to the fact that at this $\mathrm{pH}$ selenate-ion is more prone to restorative processes and may transform to selenite-ion form being more toxic for plants.

The influence of selenium on protein metabolism has been shown in this work. The content of the total protein was higher by the addition of selenium, in particular by increasing the proportion of globulins and glutelin. Earlier a number of authors also noted that the biological role of selenium in plants can be associated with its effect on the metabolism of nitrogen (Poluboyarinov and Golubkina, 2015; Reis et al., 2018).

\section{Conclusions}

The research shows that selenium is more intensively accumulated by the rye plants at initial stage of development, it is mainly concentrated in the plant's ear, and in small concentrations selenium exerts simulating effect on biomass accumulation. Thus, the findings certify to the important biological importance of selenium for growth and development of plants. However, mechanisms of protection effect of selenium in vegetative organisms remain unclarified. One of possible mechanisms of such effect is selenium antioxidant features which were proved in respect with humans and animals.

In addition, this study identified the optimum concentration of selenium supplements (0.01-0.05 mg Se kg${ }^{-1}$ soil). By these concentrations not only increase of studied plants biomass, but also achieved the necessary level of selenium $\left(100 \mu \mathrm{g} \mathrm{g} \mathrm{g}^{-1}\right)$ in cereals, which guarantees the security of this trace element humans and animals were observed. Thus, the data allow more fully uncover the function of this trace element in plants, and thus create the basis for the use of selenium-containing fertilizers is not only to increase the availability of selenium for humans and animals, but also to increase the productivity of crop production. 


\section{REFERENCES}

[1] Aissa, N., Malagoli, M., Radhouane, L. (2018): An approach to alleviate the impact of drought stress with selenium amendment. - Iranian Journal of Science and Technology, Transactions A: Science 42(1): 283-288.

[2] Bradford, M. M. (1976): A rapid and sensitive method for the quantitation of microgram quantities of protein utilizing the principle of protein-dye binding. - Analytical Biochemistry 72(1-2): 248-254.

[3] Diao, M., Ma, L., Wang, J., Cui, J., Fu, A., Liu, H. Y. (2014): Selenium promotes the growth and photosynthesis of tomato seedlings under salt stress by enhancing chloroplast antioxidant defense system. - Journal of Plant Growth Regulation 33(3): 671-682.

[4] Djanaguiraman, M., Devi, D. D., Shanker, A. K., Sheeba, J. A., Bangarusamy, U. (2004): Impact of selenium spray on monocarpic senescence of soybean (Glycine Max L.). Journal of Food Agriculture and Environment 2(2): 44-47.

[5] Djanaguiraman, M., Devi, D. D., Shanker, A. K., Sheeba, J. A., Bangarusamy, U. (2005): Selenium-an antioxidative protectant in soybean during senescence. - Plant and Soil 272(1-2): 77-86.

[6] Durán, P., Acuña, J. J., Armada, E., López-Castillo, O. M., Cornejo, P., Mora, M. L., Azcón, R. (2016): Inoculation with selenobacteria and arbuscular mycorrhizal fungi to enhance selenium content in lettuce plants and improve tolerance against drought stress. Journal of soil Science and Plant Nutrition 16(1): 211-225.

[7] El Mehdawi, A. F., Jiang, Y., Guignardi, Z. S., Esmat, A., Pilon, M., Pilon-Smits, E. A., Schiavon, M. (2018): Influence of sulfate supply on selenium uptake dynamics and expression of sulfate/selenate transporters in selenium hyperaccumulator and nonhyperaccumulator Brassicaceae. - New Phytologist 217(1): 194-205.

[8] Germ, M., Stibilj, V., Kreft, I. (2007): Metabolic Importance of Selenium for Plants. The European Journal of Plant Science and Biotechnology 1(1): 91-97.

[9] Golob, A., Stibilj, V., Kreft, I., Vogel-Mikuš, K., Gaberščik, A., Germ, M. (2018): Selenium treatment alters the effects of UV radiation on chemical and production parameters in hybrid buckwheat. - Acta Agriculturae Scandinavica, Section B-Soil \& Plant Science 68(1): 5-15.

[10] Graham, R., Stangoulis, J., Genec, Y., Lyons, G. (2005): Selenium Can Increase Growth and Fertility in Vascular Plants. - In: Li, C. et al. (eds.) Plant Nutrition for Food Security, Human Health and Environmental Protection. Tsinghua University Press, Beijing.

[11] Jiang, C., Zu, C., Lu, D., Zheng, Q., Shen, J., Wang, H., Li, D. (2017): Effect of exogenous selenium supply on photosynthesis, $\mathrm{Na}+$ accumulation and antioxidative capacity of maize (Zea mays L.) under salinity stress. - Scientific Reports 7: 42039.

[12] Hartikainen, H., Xue, T. (1999). The promotive effect of selenium on plant growth as triggered by ultraviolet irradiation. - Journal of Environmental Quality 28(4): 1372-1375.

[13] Hawrylak-Nowak, B., Matraszek, R., Pogorzelec, M. (2015): The dual effects of two inorganic selenium forms on the growth, selected physiological parameters and macronutrients accumulation in cucumber plants. - Acta Physiologiae Plantarum 37(2): 41.

[14] Kong, L., Wang, M., Bi, D. (2005): Selenium modulates the activities of antioxidant enzymes, osmotic homeostasis and promotes the growth of sorrel seedlings under salt stress. - Plant Growth Regulation 45(2): 155-163.

[15] Korzun, V., Malyshev, S., Voylokov, A. V., Börner, A. (2001): A genetic map of rye (Secale cereale L.) combining RFLP, isozyme, protein, microsatellite and gene loci. Theoretical and Applied Genetics 102(5): 709-717.

[16] Kurkova, T., Skrypnik, L., Zalieckiene, E. (2008): Features of plant material pretreatment for the selenium determination by atomic absorption and fluorometric methods. - Chemija 19(1): 40-43. 
[17] Lyons, G., Ortiz-Monasterio, I., Stangoulis, J., Graham, R. (2005): Selenium concentration in wheat grain: is there sufficient genotypic variation to use in breeding? Plant and Soil 269(1-2): 369-380.

[18] Mehdi, Y., Hornick, J. L., Istasse, L., Dufrasne, I. (2013): Selenium in the environment, metabolism and involvement in body functions. - Molecules 18(3): 3292-3311.

[19] Nawaz, F., Ahmad, R., Ashraf, M. Y., Waraich, E. A., Khan, S. Z. (2015a): Effect of selenium foliar spray on physiological and biochemical processes and chemical constituents of wheat under drought stress. - Ecotoxicology and Environmental Safety 113: 191-200.

[20] Nawaz, F., Ashraf, M. Y., Ahmad, R., Waraich, E. A., Shabbir, R. N., Bukhari, M. A. (2015b): Supplemental selenium improves wheat grain yield and quality through alterations in biochemical processes under normal and water deficit conditions. - Food Chemistry 175: 350-357.

[21] Pennanen, A., Xue, T., Hartikainen, H. (2002): Protective role of selenium in plant subjected to severe UV irradiation stress. - J. Appl. Bot.-Angew. Bot. 76: 66-76.

[22] Pihlava, J. M., Hellström, J., Kurtelius, T., Mattila, P. (2018): Flavonoids, anthocyanins, phenolamides, benzoxazinoids, lignans and alkylresorcinols in rye (Secale cereale) and some rye products. - Journal of Cereal Science 79: 183-192.

[23] Poluboyarinov, P. A., Golubkina, N. A. (2015): Investigation of biochemical function of selenium and its influence on the content of protein fractions and peroxidase activity in maize seedlings. - Russian Journal of Plant Physiology 62(3): 367-374.

[24] Reis, H. P. G., de Queiroz Barcelos, J. P., Junior, E. F., Santos, E. F., Silva, V. M., Moraes, M. F., Putti, F. F., dos Reis, A. R. (2018): Agronomic biofortification of upland rice with selenium and nitrogen and its relation to grain quality. - Journal of Cereal Science 79: 508-515.

[25] Reynolds, R. J. B., Cappa, J. J., Pilon-Smits, E. A. (2017): Evolutionary Aspects of Plant Selenium Accumulation. - In: Pilon-Smits, E., Winkel, L., Lin, Z. Q. (eds.) Selenium in Plants. Springer, Cham.

[26] Sharma, S., Gupta, R., Singh, D. (2016): Variation in selenium tolerance, accumulation, and growth parameters of different wheat cultivars. - Communications in Soil Science and Plant Analysis 47(2): 203-212.

[27] Schulz, R., Weber, M., Breuer, J., Roemheld, V. (1998): Zur Selenversorgung des Getreides in Deutschland. - VDLUFA Schriftenr. 49: 341-344.

[28] Seppänen, M., Turakainen, M., Hartikainen, H. (2003): Selenium effects on oxidative stress in potato. - Plant Science 165(2): 311-319.

[29] Sors, T. G., Ellis, D. R., Na, G. N., Lahner, B., Lee, S., Leustek, T., Pickering, I., Salt, D. E. (2005): Analysis of sulfur and selenium assimilation in Astragalus plants with varying capacities to accumulate selenium. - The Plant Journal 42(6): 785-797.

[30] Pilon-Smits, E. A. (2017): Mechanisms of Plant Selenium Hyperaccumulation. - In: Pilon-Smits, E., Winkel, L., Lin, Z. Q. (eds.) Selenium in Plants. Springer, Cham.

[31] Puccinelli, M., Malorgio, F., Pezzarossa, B. (2017): Selenium enrichment of horticultural crops. - Molecules 22(6): 933.

[32] Terry, N., Zayed, A. M., De Souza, M. P., Tarun, A. S. (2000): Selenium in higher plants. - Annual Review of Plant Biology 51(1): 401-432.

[33] Thavarajah, D., Thavarajah, P., Vial, E., Gebhardt, M., Lacher, C., Kumar, S., Combs, G. F. (2015): Will selenium increase lentil (Lens culinaris Medik) yield and seed quality? Frontiers in Plant Science 6: 356.

[34] Wang, J., Cappa, J. J., Harris, J. P., Edger, P. P., Zhou, W., Pires, J. C., Adair, M., Unruh, S. A., Simmons, M. P., Schiavon, M., Pilon-Smits, E. A. (2018): Transcriptome-wide comparison of selenium hyperaccumulator and non-accumulator Stanleya species provides new insight into key processes mediating the hyperaccumulation syndrome. Plant Biotechnology Journal. DOI: 10.1111/pbi.12897. 
[35] Wangeline, A. L., Valdez, J. R., Lindblom, S. D., Bowling, K. L., Reeves, F. B., Pilon-Smits, E. A. (2011): Characterization of rhizosphere fungi from selenium hyperaccumulator and nonhyperaccumulator plants along the eastern Rocky Mountain Front Range. - American Journal of Botany 98(7): 1139-1147.

[36] Wu, Z., Liu, S., Zhao, J., Wang, F., Du, Y., Zou, S., Huang, Y. (2017): Comparative responses to silicon and selenium in relation to antioxidant enzyme system and the glutathione-ascorbate cycle in flowering Chinese cabbage (Brassica campestris L. ssp. chinensis var. utilis) under cadmium stress. - Environmental and Experimental Botany 133: 1-11.

[37] Xu, J., Yang, F., Chen, L., Hu, Y., Hu, Q. (2003): Effect of selenium on increasing the antioxidant activity of tea leaves harvested during the early spring tea producing season. Journal of Agricultural and Food Chemistry 51(4): 1081-1084.

[38] Xue, T., Hartikainen, H. (2000): Association of antioxidative enzymes with the synergistic effect of selenium and UV irradiation in enhancing plant growth. Agricultural and Food Science in Finland 9: 177-186.

[39] Xue, T., Hartikainen, H., Piironen, V. (2001): Antioxidative and growth-promoting effect of selenium on senescing lettuce. - Plant and soil 237(1): 55-61.

[40] Zadoks, J. C., Chang, T. T., Konzak, C. F. (1974): A Decimal Code for the Growth Stages of Cereals. - Weed Research 14: 415-421.

[41] Zhao, C., Ren, J., Xue, C., Lin, E. (2005): Study on the relationship between soil selenium and plant selenium uptake. - Plant and Soil 277(1-2): 197-206.

[42] Zhu, Y. G., Pilon-Smits, E. A., Zhao, F. J., Williams, P. N., Meharg, A. A. (2009): Selenium in higher plants: understanding mechanisms for biofortification and phytoremediation. - Trends in Plant Science 14(8): 436-442.

\section{APPENDIX}

One way analysis of variance

Data source: Tillering_0

\begin{tabular}{c|c|c|c|c|c}
\hline Group Name & N & Missing & Mean & Std Dev & SEM \\
\hline $\mathrm{pH} \mathrm{5.4}$ & 4 & 0 & 0.0420 & 0.00200 & 0.001000 \\
\hline $\mathrm{pH} 6.6$ & 4 & 0 & 0.0310 & 0.00200 & 0.001000 \\
\hline
\end{tabular}

\begin{tabular}{c|c|c|c|c|c}
\hline Source of Variation & DF & SS & MS & F & P \\
\hline Between Groups & 1 & 0.000242 & 0.000242 & 60.500 & $<0.001$ \\
\hline Residual & 6 & 0.0000240 & 0.00000400 & & \\
\hline Total & 7 & 0.000266 & & & \\
\hline
\end{tabular}

The differences in the mean values among the treatment groups are greater than would be expected by chance; there is a statistically significant difference $(\mathrm{P}=<0.001)$.

Power of performed test with alpha $=0.050: 1.000$

All pairwise multiple comparison procedures (Tukey Test):

Comparisons for factor:

\begin{tabular}{c|c|c|c|c|c}
\hline Comparison & Diff of Means & p & q & P & P $<\mathbf{0 . 0 5 0}$ \\
\hline pH 5. vs. pH 6.6 & 0.0110 & 2 & 11.000 & $<0.001$ & Yes \\
\hline
\end{tabular}




$$
-2397
$$

One way analysis of variance

Data source: Tillering_0.01

\begin{tabular}{c|c|c|c|c|c}
\hline Group Name & N & Missing & Mean & Std Dev & SEM \\
\hline pH 5.4 & 4 & 0 & 0.580 & 0.0300 & 0.0150 \\
\hline pH 6.6 & 4 & 0 & 0.550 & 0.0200 & 0.01000 \\
\hline
\end{tabular}

\begin{tabular}{c|c|c|c|c|c}
\hline Source of Variation & DF & SS & MS & F & P \\
\hline Between Groups & 1 & 0.00180 & 0.00180 & 2.769 & 0.147 \\
\hline Residual & 6 & 0.00390 & 0.000650 & & \\
\hline Total & 7 & 0.00570 & & & \\
\hline
\end{tabular}

The differences in the mean values among the treatment groups are not great enough to exclude the possibility that the difference is due to random sampling variability; there is not a statistically significant difference $(\mathrm{P}=0.147)$.

Power of performed test with alpha $=0.050: 0.196$

The power of the performed test $(0.196)$ is below the desired power of 0.800 .

Less than desired power indicates you are less likely to detect a difference when one actually exists. Negative results should be interpreted cautiously.

One way analysis of variance

Data source: Tillering_0.05

\begin{tabular}{c|c|c|c|c|c}
\hline Group Name & N & Missing & Mean & Std Dev & SEM \\
\hline pH 5.4 & 4 & 0 & 2.200 & 0.1000 & 0.0500 \\
\hline pH 6.6 & 4 & 0 & 2.410 & 0.0700 & 0.0350 \\
\hline
\end{tabular}

\begin{tabular}{c|c|c|c|c|c}
\hline $\begin{array}{c}\text { Source of } \\
\text { Variation }\end{array}$ & DF & SS & MS & F & P \\
\hline Between Groups & 1 & 0.0882 & 0.0882 & 11.839 & 0.014 \\
\hline Residual & 6 & 0.0447 & 0.00745 & & \\
\hline Total & 7 & 0.133 & & & \\
\hline
\end{tabular}

The differences in the mean values among the treatment groups are greater than would be expected by chance; there is a statistically significant difference $(\mathrm{P}=0.014)$.

Power of performed test with alpha $=0.050: 0.790$

All Pairwise Multiple Comparison Procedures (Tukey Test):

Comparisons for factor:

\begin{tabular}{c|c|c|c|c|c}
\hline Comparison & Diff of Means & p & q & P & P<0.050 \\
\hline pH 5.4 vs. pH 6.6 & 0.210 & 2 & 4.866 & 0.014 & Yes \\
\hline
\end{tabular}


One way analysis of variance

Data source: Tillering_0.1

\begin{tabular}{c|c|c|c|c|c}
\hline Group Name & N & Missing & Mean & Std Dev & SEM \\
\hline $\mathrm{pH} 5.4$ & 4 & 0 & 7.400 & 0.1000 & 0.0500 \\
\hline $\mathrm{pH} 6.6$ & 4 & 0 & 9.240 & 0.0800 & 0.0400 \\
\hline
\end{tabular}

\begin{tabular}{c|c|c|c|c|c}
\hline Source of Variation & DF & SS & MS & F & P \\
\hline Between Groups & 1 & 6.771 & 6.771 & 825.756 & $<0.001$ \\
\hline Residual & 6 & 0.0492 & 0.00820 & & \\
\hline Total & 7 & 6.820 & & & \\
\hline
\end{tabular}

The differences in the mean values among the treatment groups are greater than would be expected by chance; there is a statistically significant difference $(\mathrm{P}=<0.001)$.

Power of performed test with alpha $=0.050: 1.000$

All pairwise multiple comparison procedures (Tukey Test):

Comparisons for factor:

\begin{tabular}{c|c|c|c|c|c}
\hline Comparison & Diff of Means & p & q & P & P<0.050 \\
\hline pH 5.4 vs. pH 6.6 & 1.840 & 2 & 40.639 & $<0.001$ & Yes \\
\hline
\end{tabular}

One way analysis of variance

Data source: Tillering_0.5

\begin{tabular}{c|c|c|c|c|c}
\hline Group Name & N & Missing & Mean & Std Dev & SEM \\
\hline $\mathrm{pH} 5.4$ & 4 & 0 & 56.800 & 0.700 & 0.350 \\
\hline $\mathrm{pH} 6.6$ & 4 & 0 & 59.300 & 0.400 & 0.200 \\
\hline
\end{tabular}

\begin{tabular}{c|c|c|c|c|c}
\hline Source of Variation & DF & SS & MS & F & P \\
\hline Between Groups & 1 & 12.500 & 12.500 & 38.462 & $<0.001$ \\
\hline Residual & 6 & 1.950 & 0.325 & & \\
\hline Total & 7 & 14.450 & & & \\
\hline
\end{tabular}

The differences in the mean values among the treatment groups are greater than would be expected by chance; there is a statistically significant difference $(\mathrm{P}=<0.001)$.

Power of performed test with alpha $=0.050: 0.999$

All pairwise multiple comparison procedures (Tukey Test):

Comparisons for factor:

\begin{tabular}{c|c|c|c|c|c}
\hline Comparison & Diff of Means & p & q & P & P<0.050 \\
\hline pH 5.4 vs. pH 6.6 & 2.500 & 2 & 8.771 & 0.001 & Yes \\
\hline
\end{tabular}


One way analysis of variance

Data source: Booting_0

\begin{tabular}{c|c|c|c|c|c}
\hline Group Name & N & Missing & Mean & Std Dev & SEM \\
\hline pH 5.4 & 4 & 0 & 0.0480 & 0.00400 & 0.00200 \\
\hline pH 6.6 & 4 & 0 & 0.0510 & 0.00300 & 0.00150 \\
\hline
\end{tabular}

\begin{tabular}{c|c|c|c|c|c}
\hline Source of Variation & DF & SS & MS & F & P \\
\hline Between Groups & 1 & 0.0000180 & 0.0000180 & 1.440 & 0.275 \\
\hline Residual & 6 & 0.0000750 & 0.0000125 & & \\
\hline Total & 7 & 0.0000930 & & & \\
\hline
\end{tabular}

The differences in the mean values among the treatment groups are not great enough to exclude the possibility that the difference is due to random sampling variability; there is not a statistically significant difference $(\mathrm{P}=0.275)$.

Power of performed test with alpha $=0.050: 0.084$

The power of the performed test $(0.084)$ is below the desired power of 0.800 .

Less than desired power indicates you are less likely to detect a difference when one actually exists. Negative results should be interpreted cautiously.

One way analysis of variance

Data source: Booting_0.01

\begin{tabular}{c|c|c|c|c|c}
\hline Group Name & N & Missing & Mean & Std Dev & SEM \\
\hline $\mathrm{pH} 5.4$ & 4 & 0 & 0.420 & 0.01000 & 0.00500 \\
\hline $\mathrm{pH} 6.6$ & 4 & 0 & 0.470 & 0.0300 & 0.0150 \\
\hline
\end{tabular}

\begin{tabular}{c|c|c|c|c|c}
\hline Source of Variation & DF & SS & MS & F & P \\
\hline Between Groups & 1 & 0.00500 & 0.00500 & 10.000 & 0.020 \\
\hline Residual & 6 & 0.00300 & 0.000500 & & \\
\hline Total & 7 & 0.00800 & & & \\
\hline
\end{tabular}

The differences in the mean values among the treatment groups are greater than would be expected by chance; there is a statistically significant difference $(\mathrm{P}=0.020)$.

Power of performed test with alpha $=0.050: 0.712$

All pairwise multiple comparison procedures (Tukey Test):

Comparisons for factor:

\begin{tabular}{c|c|c|c|c|c}
\hline Comparison & Diff of Means & p & q & P & P<0.050 \\
\hline pH 5.4 vs. pH 6.6 & 0.0500 & 2 & 4.472 & 0.020 & Yes \\
\hline
\end{tabular}


One way analysis of variance

Data source: Booting_0.05

\begin{tabular}{c|c|c|c|c|c}
\hline Group Name & N & Missing & Mean & Std Dev & SEM \\
\hline pH 5.4 & 4 & 0 & 1.810 & 0.0400 & 0.0200 \\
\hline pH 6.6 & 4 & 0 & 1.970 & 0.0400 & 0.0200 \\
\hline
\end{tabular}

\begin{tabular}{c|c|c|c|c|c}
\hline Source of Variation & DF & SS & MS & F & P \\
\hline Between Groups & 1 & 0.0512 & 0.0512 & 32.000 & 0.001 \\
\hline Residual & 6 & 0.00960 & 0.00160 & & \\
\hline Total & 7 & 0.0608 & & & \\
\hline
\end{tabular}

The differences in the mean values among the treatment groups are greater than would be expected by chance; there is a statistically significant difference $(P=0.001)$.

Power of performed test with alpha $=0.050: 0.997$

All pairwise multiple comparison procedures (Tukey Test):

Comparisons for factor:

\begin{tabular}{c|c|c|c|c|c}
\hline Comparison & Diff of Means & p & $\mathbf{q}$ & $\mathbf{P}$ & $\mathbf{P}<\mathbf{0 . 0 5 0}$ \\
\hline pH 5.4 vs. pH 6.6 & & 0.160 & 2 & 8.000 & 0.002 \\
\hline
\end{tabular}

One way analysis of variance

Data source: Booting_0.1

\begin{tabular}{c|c|c|c|c|c}
\hline Group Name & N & Missing & Mean & Std Dev & SEM \\
\hline $\mathrm{pH} \mathrm{5.4}$ & 4 & 0 & 4.380 & 0.0500 & 0.0250 \\
\hline $\mathrm{pH} 6.6$ & 4 & 0 & 4.940 & 0.0800 & 0.0400 \\
\hline
\end{tabular}

\begin{tabular}{c|c|c|c|c|c}
\hline Source of Variation & DF & SS & MS & F & P \\
\hline Between Groups & 1 & 0.627 & 0.627 & 140.944 & $<0.001$ \\
\hline Residual & 6 & 0.0267 & 0.00445 & & \\
\hline Total & 7 & 0.654 & & & \\
\hline
\end{tabular}

The differences in the mean values among the treatment groups are greater than would be expected by chance; there is a statistically significant difference $(\mathrm{P}=<0.001)$.

Power of performed test with alpha $=0.050: 1.000$

All pairwise multiple comparison procedures (Tukey Test):

Comparisons for factor:

\begin{tabular}{c|c|c|c|c|c}
\hline Comparison & Diff of Means & p & q & P & P<0.050 \\
\hline pH 5.4 vs. pH 6.6 & 0.560 & 2 & 16.790 & $<0.001$ & Yes \\
\hline
\end{tabular}


One way analysis of variance

Data source: Booting_0.5

\begin{tabular}{c|c|c|c|c|c}
\hline Group Name & N & Missing & Mean & Std Dev & SEM \\
\hline pH 5.4 & 4 & 0 & 24.900 & 0.1000 & 0.0500 \\
\hline pH 6.6 & 4 & 0 & 31.700 & 0.300 & 0.150 \\
\hline
\end{tabular}

\begin{tabular}{c|c|c|c|c|c}
\hline Source of Variation & DF & SS & MS & F & P \\
\hline Between Groups & 1 & 92.480 & 92.480 & 1849.600 & $<0.001$ \\
\hline Residual & 6 & 0.300 & 0.0500 & & \\
\hline Total & 7 & 92.780 & & & \\
\hline
\end{tabular}

The differences in the mean values among the treatment groups are greater than would be expected by chance; there is a statistically significant difference $(\mathrm{P}=<0.001)$.

Power of performed test with alpha $=0.050: 1.000$

All pairwise multiple comparison procedures (Tukey Test):

Comparisons for factor:

\begin{tabular}{c|c|c|c|c|c}
\hline Comparison & Diff of Means & p & q & P & P<0.050 \\
\hline pH 5.4 vs. pH 6.6 & 6.800 & 2 & 60.821 & $<0.001$ & Yes \\
\hline
\end{tabular}

One way analysis of variance

Data source: Milk development_0

\begin{tabular}{c|c|c|c|c|c}
\hline Group Name & N & Missing & Mean & Std Dev & SEM \\
\hline pH 5.4 & 4 & 0 & 0.0460 & 0.00200 & 0.001000 \\
\hline pH 6.6 & 4 & 0 & 0.0470 & 0.001000 & 0.000500 \\
\hline
\end{tabular}

\begin{tabular}{c|c|c|c|c|c}
\hline Source of Variation & DF & SS & MS & F & P \\
\hline Between Groups & 1 & 0.00000200 & 0.00000200 & 0.800 & 0.406 \\
\hline Residual & 6 & 0.0000150 & 0.00000250 & & \\
\hline Total & 7 & 0.0000170 & & & \\
\hline
\end{tabular}

The differences in the mean values among the treatment groups are not great enough to exclude the possibility that the difference is due to random sampling variability; there is not a statistically significant difference $(\mathrm{P}=0.406)$.

Power of performed test with alpha $=0.050: 0.049$

The power of the performed test (0.049) is below the desired power of 0.800 .

Less than desired power indicates you are less likely to detect a difference when one actually exists. Negative results should be interpreted cautiously. 
One way analysis of variance

Data source: Milk development_0.01

\begin{tabular}{c|c|c|c|c|c}
\hline Group Name & N & Missing & Mean & Std Dev & SEM \\
\hline $\mathrm{pH} 5.4$ & 4 & 0 & 0.167 & 0.00500 & 0.00250 \\
\hline $\mathrm{pH} 6.6$ & 4 & 0 & 0.212 & 0.00400 & 0.00200 \\
\hline
\end{tabular}

\begin{tabular}{c|c|c|c|c|c}
\hline Source of Variation & DF & SS & MS & F & P \\
\hline Between Groups & 1 & 0.00405 & 0.00405 & 197.561 & $<0.001$ \\
\hline Residual & 6 & 0.000123 & 0.0000205 & & \\
\hline Total & 7 & 0.00417 & & & \\
\hline
\end{tabular}

The differences in the mean values among the treatment groups are greater than would be expected by chance; there is a statistically significant difference $(\mathrm{P}=<0.001)$.

Power of performed test with alpha $=0.050: 1.000$

All pairwise multiple comparison procedures (Tukey Test):

Comparisons for factor:

\begin{tabular}{c|c|c|c|c|c}
\hline Comparison & Diff of Means & p & q & P & P<0.050 \\
\hline pH 5.4 vs. pH 6.6 & 0.0450 & 2 & 19.878 & $<0.001$ & Yes \\
\hline
\end{tabular}

One way analysis of variance

Data source: Milk development_0.05

\begin{tabular}{c|c|c|c|c|c}
\hline Group Name & N & Missing & Mean & Std Dev & SEM \\
\hline $\mathrm{pH} 5.4$ & 4 & 0 & 0.650 & 0.0200 & 0.01000 \\
\hline $\mathrm{pH} 6.6$ & 4 & 0 & 0.710 & 0.01000 & 0.00500 \\
\hline
\end{tabular}

\begin{tabular}{c|c|c|c|c|c}
\hline Source of Variation & DF & SS & MS & F & P \\
\hline Between Groups & 1 & 0.00720 & 0.00720 & 28.800 & 0.002 \\
\hline Residual & 6 & 0.00150 & 0.000250 & & \\
\hline Total & 7 & 0.00870 & & & \\
\hline
\end{tabular}

The differences in the mean values among the treatment groups are greater than would be expected by chance; there is a statistically significant difference $(\mathrm{P}=0.002)$.

Power of performed test with alpha $=0.050: 0.993$

All pairwise multiple comparison procedures (Tukey Test):

Comparisons for factor:

\begin{tabular}{c|c|c|c|c|c}
\hline Comparison & Diff of Means & p & q & P & P<0.050 \\
\hline pH 5.4 vs. pH 6.6 & 0.0600 & 2 & 7.589 & 0.002 & Yes \\
\hline
\end{tabular}


One way analysis of variance

Data source: Milk development_0.1

\begin{tabular}{c|c|c|c|c|c}
\hline Group Name & N & Missing & Mean & Std Dev & SEM \\
\hline $\mathrm{pH} 5.4$ & 4 & 0 & 1.420 & 0.0700 & 0.0350 \\
\hline $\mathrm{pH} 6.6$ & 4 & 0 & 1.600 & 0.1000 & 0.0500 \\
\hline
\end{tabular}

\begin{tabular}{c|c|c|c|c|c}
\hline Source of Variation & DF & SS & MS & F & P \\
\hline Between Groups & 1 & 0.0648 & 0.0648 & 8.698 & 0.026 \\
\hline Residual & 6 & 0.0447 & 0.00745 & & \\
\hline Total & 7 & 0.110 & & & \\
\hline
\end{tabular}

The differences in the mean values among the treatment groups are greater than would be expected by chance; there is a statistically significant difference $(\mathrm{P}=0.026)$.

Power of performed test with alpha $=0.050: 0.643$

All pairwise multiple comparison procedures (Tukey Test):

Comparisons for factor:

\begin{tabular}{c|c|c|c|c|c}
\hline Comparison & Diff of Means & $\mathbf{p}$ & $\mathbf{q}$ & $\mathbf{P}$ & $\mathbf{P}<\mathbf{0 . 0 5 0}$ \\
\hline pH 5.4 vs. pH 6.6 & 0.180 & 2 & 4.171 & 0.026 & Yes \\
\hline
\end{tabular}

One way analysis of variance

Data source: Milk development_0.5

\begin{tabular}{c|c|c|c|c|c}
\hline Group Name & N & Missing & Mean & Std Dev & SEM \\
\hline $\mathrm{pH} 5.4$ & 4 & 0 & 10.400 & 0.600 & 0.300 \\
\hline $\mathrm{pH} 6.6$ & 4 & 0 & 11.800 & 0.300 & 0.150 \\
\hline
\end{tabular}

\begin{tabular}{c|c|c|c|c|c}
\hline Source of Variation & DF & SS & MS & F & P \\
\hline Between Groups & 1 & 3.920 & 3.920 & 17.422 & 0.006 \\
\hline Residual & 6 & 1.350 & 0.225 & & \\
\hline Total & 7 & 5.270 & & & \\
\hline
\end{tabular}

The differences in the mean values among the treatment groups are greater than would be expected by chance; there is a statistically significant difference $(\mathrm{P}=0.006)$.

Power of performed test with alpha $=0.050: 0.927$

All pairwise multiple comparison procedures (Tukey Test):

Comparisons for factor:

\begin{tabular}{c|c|c|c|c|c}
\hline Comparison & Diff of Means & p & q & P & P $<\mathbf{0 . 0 5 0}$ \\
\hline pH 5.4 vs. pH 6.6 & 1.400 & 2 & 5.903 & 0.006 & Yes \\
\hline
\end{tabular}


One way analysis of variance

Data source: Organ_5.4_0

\begin{tabular}{c|c|c|c|c|c}
\hline Group Name & $\mathbf{N}$ & Missing & Mean & Std Dev & SEM \\
\hline Grain & 4 & 0 & 0.210 & 0.01000 & 0.00500 \\
\hline Stem & 4 & 0 & 0.120 & 0.01000 & 0.00500 \\
\hline
\end{tabular}

\begin{tabular}{c|c|c|c|c|c}
\hline Source of Variation & DF & SS & MS & F & P \\
\hline Between Groups & 1 & 0.0162 & 0.0162 & 162.000 & $<0.001$ \\
\hline Residual & 6 & 0.000600 & 0.0001000 & & \\
\hline Total & 7 & 0.0168 & & & \\
\hline
\end{tabular}

The differences in the mean values among the treatment groups are greater than would be expected by chance; there is a statistically significant difference $(\mathrm{P}=<0.001)$.

Power of performed test with alpha $=0.050: 1.000$

All pairwise multiple comparison procedures (Tukey Test):

Comparisons for factor:

\begin{tabular}{c|c|c|c|c|c}
\hline Comparison & Diff of Means & $\mathbf{p}$ & $\mathbf{q}$ & $\mathbf{P}$ & $\mathbf{P}<\mathbf{0 . 0 5 0}$ \\
\hline Grain vs. Stem & 0.0900 & 2 & 18.000 & $<0.001$ & Yes \\
\hline
\end{tabular}

One way analysis of variance

Data source: Organ_5.4_0.01

\begin{tabular}{c|c|c|c|c|c}
\hline Group Name & N & Missing & Mean & Std Dev & SEM \\
\hline Grain & 4 & 0 & 0.750 & 0.0800 & 0.0400 \\
\hline Stem & 4 & 0 & 0.420 & 0.0400 & 0.0200 \\
\hline
\end{tabular}

\begin{tabular}{c|c|c|c|c|c}
\hline Source of Variation & DF & SS & MS & F & P \\
\hline Between Groups & 1 & 0.218 & 0.218 & 54.450 & $<0.001$ \\
\hline Residual & 6 & 0.0240 & 0.00400 & & \\
\hline Total & 7 & 0.242 & & & \\
\hline
\end{tabular}

The differences in the mean values among the treatment groups are greater than would be expected by chance; there is a statistically significant difference $(\mathrm{P}=<0.001)$.

Power of performed test with alpha $=0.050: 1.000$

All pairwise multiple comparison procedures (Tukey Test):

Comparisons for factor:

\begin{tabular}{c|c|c|c|c|c}
\hline Comparison & Diff of Means & $\mathbf{p}$ & $\mathbf{q}$ & $\mathbf{P}$ & $\mathbf{P}<\mathbf{0 . 0 5 0}$ \\
\hline Grain vs. Stem & & 0.330 & 2 & 10.436 & $<0.001$ \\
\hline
\end{tabular}


One way analysis of variance

Data source: Organ_5.4_0.05

\begin{tabular}{c|c|c|c|c|c}
\hline Group Name & N & Missing & Mean & Std Dev & SEM \\
\hline Grain & 4 & 0 & 2.700 & 0.1000 & 0.0500 \\
\hline Stem & 4 & 0 & 1.590 & 0.0900 & 0.0450 \\
\hline
\end{tabular}

\begin{tabular}{c|c|c|c|c|c}
\hline Source of Variation & DF & SS & MS & F & P \\
\hline Between Groups & 1 & 2.464 & 2.464 & 272.287 & $<0.001$ \\
\hline Residual & 6 & 0.0543 & 0.00905 & & \\
\hline Total & 7 & 2.519 & & & \\
\hline
\end{tabular}

The differences in the mean values among the treatment groups are greater than would be expected by chance; there is a statistically significant difference $(\mathrm{P}=<0.001)$.

Power of performed test with alpha $=0.050: 1.000$

All pairwise multiple comparison procedures (Tukey Test):

Comparisons for factor:

\begin{tabular}{c|c|c|c|c|c}
\hline Comparison & Diff of Means & $\mathbf{p}$ & $\mathbf{q}$ & $\mathbf{P}$ & $\mathbf{P}<\mathbf{0 . 0 5 0}$ \\
\hline Grain vs. Stem & 1.110 & 2 & 23.336 & $<0.001$ & Yes \\
\hline
\end{tabular}

One way analysis of variance

Data source: Organ_5.4_0.1

\begin{tabular}{c|c|c|c|c|c}
\hline Group Name & N & Missing & Mean & Std Dev & SEM \\
\hline Grain & 4 & 0 & 6.400 & 0.500 & 0.250 \\
\hline Stem & 4 & 0 & 3.400 & 0.500 & 0.250 \\
\hline
\end{tabular}

\begin{tabular}{c|c|c|c|c|c|c}
\hline Source of Variation & DF & SS & MS & F & P & \\
\hline Between Groups & 1 & 18.000 & 18.000 & 72.000 & $<0.001$ & \\
\hline Residual & 6 & 1.500 & 0.250 & & & \\
\hline Total & 7 & 19.500 & & & & \\
\hline
\end{tabular}

The differences in the mean values among the treatment groups are greater than would be expected by chance; there is a statistically significant difference $(\mathrm{P}=<0.001)$.

Power of performed test with alpha $=0.050: 1.000$

All pairwise multiple comparison procedures (Tukey Test):

Comparisons for factor:

\begin{tabular}{c|c|c|c|c|c}
\hline Comparison & Diff of Means & $\mathbf{p}$ & $\mathbf{q}$ & $\mathbf{P}$ & $\mathbf{P}<\mathbf{0 . 0 5 0}$ \\
\hline Grain vs. Stem & 3.000 & 2 & 12.000 & $<0.001$ & Yes \\
\hline
\end{tabular}


One way analysis of variance

Data source: Organ_5.4_0.5

\begin{tabular}{c|c|c|c|c|c}
\hline Group Name & $\mathbf{N}$ & Missing & Mean & Std Dev & SEM \\
\hline Grain & 4 & 0 & 35.400 & 1.300 & 0.650 \\
\hline Stem & 4 & 0 & 33.100 & 1.700 & 0.850 \\
\hline
\end{tabular}

\begin{tabular}{c|c|c|c|c|c}
\hline Source of Variation & DF & SS & MS & F & P \\
\hline Between Groups & 1 & 10.580 & 10.580 & 4.620 & 0.075 \\
\hline Residual & 6 & 13.740 & 2.290 & & \\
\hline Total & 7 & 24.320 & & & \\
\hline
\end{tabular}

The differences in the mean values among the treatment groups are not great enough to exclude the possibility that the difference is due to random sampling variability; there is not a statistically significant difference $(\mathrm{P}=0.075)$.

Power of performed test with alpha $=0.050: 0.353$

The power of the performed test (0.353) is below the desired power of 0.800 .

Less than desired power indicates you are less likely to detect a difference when one actually exists. Negative results should be interpreted cautiously.

One way analysis of variance

Data source: Organ_6.6_0

\begin{tabular}{c|c|c|c|c|c}
\hline Group Name & $\mathbf{N}$ & Missing & Mean & Std Dev & SEM \\
\hline Grain & 4 & 0 & 0.180 & 0.0400 & 0.0200 \\
\hline Stem & 4 & 0 & 0.110 & 0.01000 & 0.00500 \\
\hline
\end{tabular}

\begin{tabular}{c|c|c|c|c|c}
\hline Source of Variation & DF & SS & MS & F & P \\
\hline Between Groups & 1 & 0.00980 & 0.00980 & 11.529 & 0.015 \\
\hline Residual & 6 & 0.00510 & 0.000850 & & \\
\hline Total & 7 & 0.0149 & & & \\
\hline
\end{tabular}

The differences in the mean values among the treatment groups are greater than would be expected by chance; there is a statistically significant difference $(\mathrm{P}=0.015)$.

Power of performed test with alpha $=0.050: 0.778$

All pairwise multiple comparison procedures (Tukey Test):

Comparisons for factor:

\begin{tabular}{c|c|c|c|c|c}
\hline Comparison & Diff of Means & $\mathbf{p}$ & $\mathbf{q}$ & $\mathbf{P}$ & $\mathbf{P}<\mathbf{0 . 0 5 0}$ \\
\hline Grain vs. Stem & 0.0700 & 2 & 4.802 & 0.015 & Yes \\
\hline
\end{tabular}


One way analysis of variance

Data source: Organ_6.6_0.01

\begin{tabular}{c|c|c|c|c|c}
\hline Group Name & $\mathbf{N}$ & Missing & Mean & Std Dev & SEM \\
\hline Grain & 4 & 0 & 0.820 & 0.0500 & 0.0250 \\
\hline Stem & 4 & 0 & 0.520 & 0.0300 & 0.0150 \\
\hline
\end{tabular}

\begin{tabular}{c|c|c|c|c|c}
\hline Source of Variation & DF & SS & MS & F & P \\
\hline Between Groups & 1 & 0.180 & 0.180 & 105.882 & $<0.001$ \\
\hline Residual & 6 & 0.0102 & 0.00170 & & \\
\hline Total & 7 & 0.190 & & & \\
\hline
\end{tabular}

The differences in the mean values among the treatment groups are greater than would be expected by chance; there is a statistically significant difference $(\mathrm{P}=<0.001)$.

Power of performed test with alpha $=0.050: 1.000$

All pairwise multiple comparison procedures (Tukey Test):

Comparisons for factor:

\begin{tabular}{c|c|c|c|c|c}
\hline Comparison & Diff of Means & $\mathbf{p}$ & $\mathbf{q}$ & $\mathbf{P}$ & $\mathbf{P}<\mathbf{0 . 0 5 0}$ \\
\hline Grain vs. Stem & & 0.300 & 2 & 14.552 & $<0.001$ \\
\hline
\end{tabular}

One way analysis of variance

Data source: Organ_6.6_0.05

\begin{tabular}{c|c|c|c|c|c}
\hline Group Name & N & Missing & Mean & Std Dev & SEM \\
\hline Grain & 4 & 0 & 2.930 & 0.0300 & 0.0150 \\
\hline Stem & 4 & 0 & 1.750 & 0.0400 & 0.0200 \\
\hline
\end{tabular}

\begin{tabular}{c|c|c|c|c|c}
\hline Source of Variation & DF & SS & MS & F & P \\
\hline Between Groups & 1 & 2.785 & 2.785 & 2227.840 & $<0.001$ \\
\hline Residual & 6 & 0.00750 & 0.00125 & & \\
\hline Total & 7 & 2.792 & & & \\
\hline
\end{tabular}

The differences in the mean values among the treatment groups are greater than would be expected by chance; there is a statistically significant difference $(\mathrm{P}=<0.001)$.

Power of performed test with alpha $=0.050: 1.000$

All pairwise multiple comparison procedures (Tukey Test):

Comparisons for factor:

\begin{tabular}{c|c|c|c|c|c}
\hline Comparison & Diff of Means & $\mathbf{p}$ & $\mathbf{q}$ & $\mathbf{P}$ & $\mathbf{P}<\mathbf{0 . 0 5 0}$ \\
\hline Grain vs. Stem & & 1.180 & 2 & 66.751 & $<0.001$ \\
\hline
\end{tabular}




$$
-2408-
$$

One way analysis of variance

Data source: Organ_6.6_0.1

\begin{tabular}{c|c|c|c|c|c}
\hline Group Name & N & Missing & Mean & Std Dev & SEM \\
\hline Grain & 4 & 0 & 6.100 & 0.200 & 0.1000 \\
\hline Stem & 4 & 0 & 4.500 & 0.200 & 0.1000 \\
\hline
\end{tabular}

\begin{tabular}{c|c|c|c|c|c}
\hline Source of Variation & DF & SS & MS & F & P \\
\hline Between Groups & 1 & 5.120 & 5.120 & 128.000 & $<0.001$ \\
\hline Residual & 6 & 0.240 & 0.0400 & & \\
\hline Total & 7 & 5.360 & & & \\
\hline
\end{tabular}

The differences in the mean values among the treatment groups are greater than would be expected by chance; there is a statistically significant difference $(\mathrm{P}=<0.001)$.

Power of performed test with alpha $=0.050: 1.000$

All pairwise multiple comparison procedures (Tukey Test):

Comparisons for factor:

\begin{tabular}{c|c|c|c|c|c}
\hline Comparison & Diff of Means & $\mathbf{p}$ & $\mathbf{q}$ & $\mathbf{P}$ & $\mathbf{P}<\mathbf{0 . 0 5 0}$ \\
\hline Grain vs. Stem & 1.600 & 2 & 16.000 & $<0.001$ & Yes \\
\hline
\end{tabular}

One way analysis of variance

Data source: Organ_6.6_0.5

\begin{tabular}{c|c|c|c|c|c}
\hline Group Name & $\mathbf{N}$ & Missing & Mean & Std Dev & SEM \\
\hline Grain & 4 & 0 & 38.300 & 1.200 & 0.600 \\
\hline Stem & 4 & 0 & 35.100 & 0.600 & 0.300 \\
\hline
\end{tabular}

\begin{tabular}{c|c|c|c|c|c}
\hline Source of Variation & DF & SS & MS & F & P \\
\hline Between Groups & 1 & 20.480 & 20.480 & 22.756 & 0.003 \\
\hline Residual & 6 & 5.400 & 0.900 & & \\
\hline Total & 7 & 25.880 & & & \\
\hline
\end{tabular}

The differences in the mean values among the treatment groups are greater than would be expected by chance; there is a statistically significant difference $(\mathrm{P}=0.003)$.

Power of performed test with alpha $=0.050: 0.975$

All pairwise multiple comparison procedures (Tukey Test):

Comparisons for factor:

\begin{tabular}{c|c|c|c|c|c}
\hline Comparison & Diff of Means & $\mathbf{p}$ & $\mathbf{q}$ & $\mathbf{P}$ & $\mathbf{P}<\mathbf{0 . 0 5 0}$ \\
\hline Grain vs. Stem & & 3.200 & 2 & 6.746 & 0.003 \\
\hline & & & & & \\
\hline
\end{tabular}


One way analysis of variance

Data source: Tillering_5.4

\begin{tabular}{c|c|c|c|c|c}
\hline Group Name & $\mathbf{N}$ & Missing & Mean & Std Dev & SEM \\
\hline 0 & 4 & 0 & 0.0740 & 0.00400 & 0.00200 \\
\hline 0.01 & 4 & 0 & 0.0810 & 0.00200 & 0.001000 \\
\hline 0.05 & 4 & 0 & 0.0750 & 0.00400 & 0.00200 \\
\hline 0.1 & 4 & 0 & 0.0770 & 0.00500 & 0.00250 \\
\hline 0.5 & 4 & 0 & 0.0730 & 0.00400 & 0.00200 \\
\hline
\end{tabular}

\begin{tabular}{c|c|c|c|c|c}
\hline Source of Variation & DF & SS & MS & F & P \\
\hline Between Groups & 4 & 0.000160 & 0.0000400 & 2.597 & 0.079 \\
\hline Residual & 15 & 0.000231 & 0.0000154 & & \\
\hline Total & 19 & 0.000391 & & & \\
\hline
\end{tabular}

The differences in the mean values among the treatment groups are not great enough to exclude the possibility that the difference is due to random sampling variability; there is not a statistically significant difference $(\mathrm{P}=0.079)$.

Power of performed test with alpha $=0.050: 0.371$

The power of the performed test $(0.371)$ is below the desired power of 0.800 .

Less than desired power indicates you are less likely to detect a difference when one actually exists. Negative results should be interpreted cautiously.

One way analysis of variance

Data source: Tillering_6.6

\begin{tabular}{c|c|c|c|c|c}
\hline Group Name & $\mathbf{N}$ & Missing & Mean & Std Dev & SEM \\
\hline 0 & 4 & 0 & 0.0720 & 0.00500 & 0.00250 \\
\hline 0.01 & 4 & 0 & 0.0830 & 0.00500 & 0.00250 \\
\hline 0.05 & 4 & 0 & 0.0780 & 0.00300 & 0.00150 \\
\hline 0.1 & 4 & 0 & 0.0720 & 0.001000 & 0.000500 \\
\hline 0.5 & 4 & 0 & 0.0710 & 0.001000 & 0.000500 \\
\hline
\end{tabular}

\begin{tabular}{c|c|c|c|c|c}
\hline Source of Variation & DF & SS & MS & F & P \\
\hline Between Groups & 4 & 0.000427 & 0.000107 & 8.754 & $<0.001$ \\
\hline Residual & 15 & 0.000183 & 0.0000122 & & \\
\hline Total & 19 & 0.000610 & & & \\
\hline
\end{tabular}

The differences in the mean values among the treatment groups are greater than would be expected by chance; there is a statistically significant difference $(\mathrm{P}=<0.001)$.

Power of performed test with alpha $=0.050: 0.983$

All pairwise multiple comparison procedures (Tukey Test):

Comparisons for factor: 


\begin{tabular}{c|c|c|c|c|c}
\hline Comparison & Diff of Means & $\mathbf{p}$ & $\mathbf{q}$ & $\mathbf{P}$ & $\mathbf{P}<\mathbf{0 . 0 5 0}$ \\
\hline 0.01 vs. 0.5 & 0.0120 & 5 & 6.871 & 0.002 & Yes \\
\hline 0.01 vs. 0.1 & 0.0110 & 5 & 6.299 & 0.004 & Yes \\
\hline 0.01 vs. 0 & 0.0110 & 5 & 6.299 & 0.004 & Yes \\
\hline 0.01 vs. 0.05 & 0.00500 & 5 & 2.863 & 0.302 & No \\
\hline 0.05 vs. 0.5 & 0.00700 & 5 & 4.008 & 0.080 & No \\
\hline 0.05 vs. 0.1 & 0.00600 & 5 & 3.436 & 0.161 & Do Not Test \\
\hline 0.05 vs. 0 & 0.00600 & 5 & 3.436 & 0.161 & Do Not Test \\
\hline 0 vs. 0.5 & 0.001000 & 5 & 0.573 & 0.994 & Do Not Test \\
\hline 0 vs. 0.1 & 0.000 & 5 & 0.000 & 1.000 & Do Not Test \\
\hline 0.1 vs. 0.5 & 0.001000 & 5 & 0.573 & 0.994 & Do Not Test \\
\hline
\end{tabular}

A result of "Do Not Test" occurs for a comparison when no significant difference is found between two means that enclose that comparison. For example, if you had four means sorted in order, and found no difference between means 4 vs. 2, then you would not test 4 vs. 3 and 3 vs. 2 , but still test 4 vs. 1 and 3 vs. 1 ( 4 vs. 3 and 3 vs. 2 are enclosed by 4 vs. 2: 432 1). Note that not testing the enclosed means is a procedural rule, and a result of Do Not Test should be treated as if there is no significant difference between the means, even though one may appear to exist.

One way analysis of variance

Data source: Booting_5.4

\begin{tabular}{c|c|c|c|c|c}
\hline Group Name & $\mathbf{N}$ & Missing & Mean & Std Dev & SEM \\
\hline 0 & 4 & 0 & 1.390 & 0.0240 & 0.0120 \\
\hline 0.01 & 4 & 0 & 1.420 & 0.0160 & 0.00800 \\
\hline 0.05 & 4 & 0 & 1.470 & 0.0180 & 0.00900 \\
\hline 0.1 & 4 & 0 & 1.480 & 0.0240 & 0.0120 \\
\hline 0.5 & 4 & 0 & 1.380 & 0.0200 & 0.01000 \\
\hline
\end{tabular}

\begin{tabular}{c|c|c|c|c|c}
\hline Source of Variation & DF & SS & MS & F & P \\
\hline Between Groups & 4 & 0.0331 & 0.00828 & 19.418 & $<0.001$ \\
\hline Residual & 15 & 0.00640 & 0.000426 & & \\
\hline Total & 19 & 0.0395 & & & \\
\hline
\end{tabular}

The differences in the mean values among the treatment groups are greater than would be expected by chance; there is a statistically significant difference $(\mathrm{P}=<0.001)$.

Power of performed test with alpha $=0.050: 1.000$

All pairwise multiple comparison procedures (Tukey Test):

Comparisons for factor:

\begin{tabular}{c|c|c|c|c|c}
\hline Comparison & Diff of Means & $\mathbf{p}$ & $\mathbf{q}$ & $\mathbf{P}$ & $\mathbf{P}<\mathbf{0 . 0 5 0}$ \\
\hline 0.1 vs. 0.5 & 0.100 & 5 & 9.685 & $<0.001$ & Yes \\
\hline 0.1 vs. 0 & 0.0900 & 5 & 8.717 & $<0.001$ & Yes \\
\hline 0.1 vs. 0.01 & 0.0600 & 5 & 5.811 & 0.007 & Yes \\
\hline 0.1 vs. 0.05 & 0.01000 & 5 & 0.969 & 0.957 & No \\
\hline
\end{tabular}




\begin{tabular}{c|c|c|c|c|c}
\hline 0.05 vs. 0.5 & 0.0900 & 5 & 8.717 & $<0.001$ & Yes \\
\hline 0.05 vs. 0 & 0.0800 & 5 & 7.748 & $<0.001$ & Yes \\
\hline 0.05 vs. 0.01 & 0.0500 & 5 & 4.843 & 0.027 & Yes \\
\hline 0.01 vs. 0.5 & 0.0400 & 5 & 3.874 & 0.094 & No \\
\hline 0.01 vs. 0 & 0.0300 & 5 & 2.906 & 0.289 & Do Not Test \\
\hline 0 vs. 0.5 & 0.01000 & 5 & 0.969 & 0.957 & Do Not Test \\
\hline
\end{tabular}

A result of "Do Not Test" occurs for a comparison when no significant difference is found between two means that enclose that comparison. For example, if you had four means sorted in order, and found no difference between means 4 vs. 2, then you would not test 4 vs. 3 and 3 vs. 2, but still test 4 vs. 1 and 3 vs. 1 ( 4 vs. 3 and 3 vs. 2 are enclosed by 4 vs. $2: 432$ 1). Note that not testing the enclosed means is a procedural rule, and a result of Do Not Test should be treated as if there is no significant difference between the means, even though one may appear to exist.

\section{One way analysis of variance}

Data source: Booting_6.6

\begin{tabular}{c|c|c|c|c|c}
\hline Group Name & $\mathbf{N}$ & Missing & Mean & Std Dev & SEM \\
\hline 0 & 4 & 0 & 1.220 & 0.0380 & 0.0190 \\
\hline 0.01 & 4 & 0 & 1.440 & 0.0310 & 0.0155 \\
\hline 0.05 & 4 & 0 & 1.430 & 0.0180 & 0.00900 \\
\hline 0.1 & 4 & 0 & 1.460 & 0.0460 & 0.0230 \\
\hline 0.5 & 4 & 0 & 1.440 & 0.0360 & 0.0180 \\
\hline
\end{tabular}

\begin{tabular}{c|c|c|c|c|c}
\hline Source of Variation & DF & SS & MS & F & P \\
\hline Between Groups & 4 & 0.160 & 0.0401 & 32.633 & $<0.001$ \\
\hline Residual & 15 & 0.0184 & 0.00123 & & \\
\hline Total & 19 & 0.179 & & & \\
\hline
\end{tabular}

The differences in the mean values among the treatment groups are greater than would be expected by chance; there is a statistically significant difference $(\mathrm{P}=<0.001)$.

Power of performed test with alpha $=0.050: 1.000$

All pairwise multiple comparison procedures (Tukey Test):

Comparisons for factor:

\begin{tabular}{c|c|c|c|c|c}
\hline Comparison & Diff of Means & $\mathbf{p}$ & $\mathbf{q}$ & $\mathbf{P}$ & $\mathbf{P}<\mathbf{0 . 0 5 0}$ \\
\hline 0.1 vs. 0 & 0.240 & 5 & 13.696 & $<0.001$ & Yes \\
\hline 0.1 vs. 0.05 & 0.0300 & 5 & 1.712 & 0.746 & No \\
\hline 0.1 vs. 0.5 & 0.0200 & 5 & 1.141 & 0.924 & Do Not Test \\
\hline 0.01 vs. 0.01 & 0.0200 & 5 & 1.141 & 0.924 & Do Not Test \\
\hline 0.01 vs. 0 & 0.220 & 5 & 12.555 & $<0.001$ & Yes \\
\hline 0.01 vs. 0.05 & 0.01000 & 5 & 0.571 & 0.994 & Do Not Test \\
\hline 0.01 vs. 0.5 & 0.000 & 5 & 0.000 & 1.000 & Do Not Test \\
\hline 0.5 vs. 0 & 0.220 & 5 & 12.555 & $<0.001$ & Yes \\
\hline 0.5 vs. 0.05 & 0.01000 & 5 & 0.571 & 0.994 & Do Not Test \\
\hline 0.05 vs. 0 & 0.210 & 5 & 11.984 & $<0.001$ & Yes \\
\hline
\end{tabular}




$$
-2412-
$$

A result of "Do Not Test" occurs for a comparison when no significant difference is found between two means that enclose that comparison. For example, if you had four means sorted in order, and found no difference between means 4 vs. 2, then you would not test 4 vs. 3 and 3 vs. 2, but still test 4 vs. 1 and 3 vs. 1 ( 4 vs. 3 and 3 vs. 2 are enclosed by 4 vs. 2: 432 1). Note that not testing the enclosed means is a procedural rule, and a result of Do Not Test should be treated as if there is no significant difference between the means, even though one may appear to exist.

\section{One way analysis of variance}

Data source: Milk development_5.4

\begin{tabular}{c|c|c|c|c|c}
\hline Group Name & $\mathbf{N}$ & Missing & Mean & Std Dev & SEM \\
\hline 0 & 4 & 0 & 6.730 & 0.0290 & 0.0145 \\
\hline 0.01 & 4 & 0 & 6.540 & 0.0490 & 0.0245 \\
\hline 0.05 & 4 & 0 & 6.420 & 0.0650 & 0.0325 \\
\hline 0.1 & 4 & 0 & 6.280 & 0.0570 & 0.0285 \\
\hline 0.5 & 4 & 0 & 6.240 & 0.0480 & 0.0240 \\
\hline
\end{tabular}

\begin{tabular}{c|c|c|c|c|c}
\hline Source of Variation & DF & SS & MS & F & P \\
\hline Between Groups & 4 & 0.640 & 0.160 & 61.475 & $<0.001$ \\
\hline Residual & 15 & 0.0391 & 0.00260 & & \\
\hline Total & 19 & 0.679 & & & \\
\hline
\end{tabular}

The differences in the mean values among the treatment groups are greater than would be expected by chance; there is a statistically significant difference $(\mathrm{P}=<0.001)$.

Power of performed test with alpha $=0.050: 1.000$

All pairwise multiple comparison procedures (Tukey Test):

Comparisons for factor:

\begin{tabular}{c|c|c|c|c|c}
\hline Comparison & Diff of Means & $\mathbf{p}$ & $\mathbf{q}$ & $\mathbf{P}$ & $\mathbf{P}<\mathbf{0 . 0 5 0}$ \\
\hline 0 vs. 0.5 & 0.490 & 5 & 19.205 & $<0.001$ & Yes \\
\hline 0 vs. 0.1 & 0.450 & 5 & 17.637 & $<0.001$ & Yes \\
\hline 0 vs. 0.05 & 0.310 & 5 & 12.150 & $<0.001$ & Yes \\
\hline 0 vs. 0.01 & 0.190 & 5 & 7.447 & $<0.001$ & Yes \\
\hline 0.01 vs. 0.5 & 0.300 & 5 & 11.758 & $<0.001$ & Yes \\
\hline 0.01 vs. 0.1 & 0.260 & 5 & 10.190 & $<0.001$ & Yes \\
\hline 0.01 vs. 0.05 & 0.120 & 5 & 4.703 & 0.032 & Yes \\
\hline 0.05 vs. 0.5 & 0.180 & 5 & 7.055 & 0.001 & Yes \\
\hline 0.05 vs. 0.1 & 0.140 & 5 & 5.487 & 0.011 & Yes \\
\hline 0.1 vs. 0.5 & 0.0400 & 5 & 1.568 & 0.800 & No
\end{tabular}


One way analysis of variance

Data source: Milk development_6.6

\begin{tabular}{c|c|c|c|c|c}
\hline Group Name & $\mathbf{N}$ & Missing & Mean & Std Dev & SEM \\
\hline 0 & 4 & 0 & 6.410 & 0.0800 & 0.0400 \\
\hline 0.01 & 4 & 0 & 6.790 & 0.0470 & 0.0235 \\
\hline 0.05 & 4 & 0 & 6.680 & 0.0690 & 0.0345 \\
\hline 0.1 & 4 & 0 & 6.470 & 0.0490 & 0.0245 \\
\hline 0.5 & 4 & 0 & 6.320 & 0.0220 & 0.0110 \\
\hline
\end{tabular}

\begin{tabular}{c|c|c|c|c|c}
\hline Source of Variation & DF & SS & MS & F & P \\
\hline Between Groups & 4 & 0.608 & 0.152 & 46.792 & $<0.001$ \\
\hline Residual & 15 & 0.0488 & 0.00325 & & \\
\hline Total & 19 & 0.657 & & & \\
\hline
\end{tabular}

The differences in the mean values among the treatment groups are greater than would be expected by chance; there is a statistically significant difference $(\mathrm{P}=<0.001)$.

Power of performed test with alpha $=0.050: 1.000$

All pairwise multiple comparison procedures (Tukey Test):

Comparisons for factor:

\begin{tabular}{c|c|c|c|c|c}
\hline Comparison & Diff of Means & $\mathbf{p}$ & $\mathbf{q}$ & $\mathbf{P}$ & $\mathbf{P}<\mathbf{0 . 0 5 0}$ \\
\hline 0.01 vs. 0.5 & 0.470 & 5 & 16.486 & $<0.001$ & Yes \\
\hline 0.01 vs. 0 & 0.380 & 5 & 13.329 & $<0.001$ & Yes \\
\hline 0.01 vs. 0.1 & 0.320 & 5 & 11.225 & $<0.001$ & Yes \\
\hline 0.01 vs. 0.05 & 0.110 & 5 & 3.858 & 0.096 & No \\
\hline 0.05 vs. 0.5 & 0.360 & 5 & 12.628 & $<0.001$ & Yes \\
\hline 0.05 vs. 0 & 0.270 & 5 & 9.471 & $<0.001$ & Yes \\
\hline 0.05 vs. 0.01 & 0.210 & 5 & 7.366 & $<0.001$ & Yes \\
\hline 0.01 vs. 0.5 & 0.150 & 5 & 5.262 & 0.015 & Yes \\
\hline 0.01 vs. 0 & 0.0600 & 5 & 2.105 & 0.585 & No \\
\hline 0 vs. 0.5 & 0.0900 & 5 & 3.157 & 0.221 & No \\
\hline
\end{tabular}

One way analysis of variance

Data source: Stem_5.4

\begin{tabular}{c|c|c|c|c|c}
\hline Group Name & $\mathbf{N}$ & Missing & Mean & Std Dev & SEM \\
\hline 0 & 4 & 0 & 2.670 & 0.0420 & 0.0210 \\
\hline 0.01 & 4 & 0 & 2.610 & 0.0440 & 0.0220 \\
\hline 0.05 & 4 & 0 & 2.630 & 0.0230 & 0.0115 \\
\hline 0.1 & 4 & 0 & 2.540 & 0.0310 & 0.0155 \\
\hline 0.5 & 4 & 0 & 2.590 & 0.0310 & 0.0155 \\
\hline
\end{tabular}




\begin{tabular}{c|c|c|c|c|c}
\hline Source of Variation & DF & SS & MS & F & P \\
\hline Between Groups & 4 & 0.0371 & 0.00928 & 7.543 & 0.002 \\
\hline Residual & 15 & 0.0185 & 0.00123 & & \\
\hline Total & 19 & 0.0556 & & & \\
\hline
\end{tabular}

The differences in the mean values among the treatment groups are greater than would be expected by chance; there is a statistically significant difference $(\mathrm{P}=0.002)$.

Power of performed test with alpha $=0.050: 0.959$

All pairwise multiple comparison procedures (Tukey Test):

Comparisons for factor:

\begin{tabular}{c|c|c|c|c|c}
\hline Comparison & Diff of Means & $\mathbf{p}$ & $\mathbf{q}$ & $\mathbf{P}$ & P<0.050 \\
\hline 0 vs. 0.1 & 0.130 & 5 & 7.413 & $<0.001$ & Yes \\
\hline 0 vs. 0.5 & 0.0800 & 5 & 4.562 & 0.039 & Yes \\
\hline 0 vs. 0.01 & 0.0600 & 5 & 3.421 & 0.164 & No \\
\hline 0 vs. 0.05 & 0.0400 & 5 & 2.281 & 0.512 & Do Not Test \\
\hline 0.05 vs. 0.1 & 0.0900 & 5 & 5.132 & 0.018 & Yes \\
\hline 0.05 vs. 0.5 & 0.0400 & 5 & 2.281 & 0.512 & No \\
\hline 0.05 vs. 0.01 & 0.0200 & 5 & 1.140 & 0.925 & Do Not Test \\
\hline 0.01 vs. 0.1 & 0.0700 & 5 & 3.992 & 0.081 & No \\
\hline 0.01 vs. 0.5 & 0.0200 & 5 & 1.140 & 0.925 & Do Not Test \\
\hline 0.5 vs. 0.1 & 0.0500 & 5 & 2.851 & 0.305 & Do Not Test
\end{tabular}

A result of "Do Not Test" occurs for a comparison when no significant difference is found between two means that enclose that comparison. For example, if you had four means sorted in order, and found no difference between means 4 vs. 2, then you would not test 4 vs. 3 and 3 vs. 2, but still test 4 vs. 1 and 3 vs. 1 ( 4 vs. 3 and 3 vs. 2 are enclosed by 4 vs. 2: 432 1). Note that not testing the enclosed means is a procedural rule, and a result of Do Not Test should be treated as if there is no significant difference between the means, even though one may appear to exist.

One way analysis of variance

Data source: Stem_6.6

\begin{tabular}{c|c|c|c|c|c}
\hline Group Name & $\mathbf{N}$ & Missing & Mean & Std Dev & SEM \\
\hline 0 & 4 & 0 & 2.620 & 0.0340 & 0.0170 \\
\hline 0.01 & 4 & 0 & 2.840 & 0.0410 & 0.0205 \\
\hline 0.05 & 4 & 0 & 2.540 & 0.0300 & 0.0150 \\
\hline 0.1 & 4 & 0 & 2.530 & 0.0220 & 0.0110 \\
\hline 0.5 & 4 & 0 & 2.410 & 0.0210 & 0.0105 \\
\hline
\end{tabular}

\begin{tabular}{c|c|c|c|c|c}
\hline Source of Variation & DF & SS & MS & F & P \\
\hline Between Groups & 4 & 0.408 & 0.102 & 109.266 & $<0.001$ \\
\hline Residual & 15 & 0.0140 & 0.000932 & & \\
\hline Total & 19 & 0.422 & & & \\
\hline
\end{tabular}




$$
-2415
$$

The differences in the mean values among the treatment groups are greater than would be expected by chance; there is a statistically significant difference $(\mathrm{P}=<0.001)$.

Power of performed test with alpha $=0.050: 1.000$

All pairwise multiple comparison procedures (Tukey Test):

Comparisons for factor:

\begin{tabular}{c|c|c|c|c|c}
\hline Comparison & Diff of Means & $\mathbf{p}$ & $\mathbf{q}$ & $\mathbf{P}$ & $\mathbf{P}<\mathbf{0 . 0 5 0}$ \\
\hline 0.01 vs. 0.5 & 0.430 & 5 & 28.164 & $<0.001$ & Yes \\
\hline 0.01 vs. 0.1 & 0.310 & 5 & 20.304 & $<0.001$ & Yes \\
\hline 0.01 vs. 0.05 & 0.300 & 5 & 19.649 & $<0.001$ & Yes \\
\hline 0.01 vs. 0 & 0.220 & 5 & 14.410 & $<0.001$ & Yes \\
\hline 0 vs. 0.5 & 0.210 & 5 & 13.755 & $<0.001$ & Yes \\
\hline 0 vs. 0.1 & 0.0900 & 5 & 5.895 & 0.006 & Yes \\
\hline 0 vs. 0.05 & 0.0800 & 5 & 5.240 & 0.016 & Yes \\
\hline 0.05 vs. 0.5 & 0.130 & 5 & 8.515 & $<0.001$ & Yes \\
\hline 0.05 vs. 0.1 & 0.0100 & 5 & 0.655 & 0.990 & No \\
\hline 0.1 vs. 0.5 & 0.120 & 5 & 7.860 & $<0.001$ & Yes
\end{tabular}

One way analysis of variance

Data source: Grain_5.4

\begin{tabular}{c|c|c|c|c|c}
\hline Group Name & $\mathbf{N}$ & Missing & Mean & Std Dev & SEM \\
\hline 0 & 4 & 0 & 4.020 & 0.0300 & 0.0150 \\
\hline 0.01 & 4 & 0 & 3.900 & 0.0300 & 0.0150 \\
\hline 0.05 & 4 & 0 & 3.830 & 0.0530 & 0.0265 \\
\hline 0.1 & 4 & 0 & 3.750 & 0.0650 & 0.0325 \\
\hline 0.5 & 4 & 0 & 3.670 & 0.0400 & 0.0200 \\
\hline
\end{tabular}

\begin{tabular}{c|c|c|c|c|c}
\hline Source of Variation & DF & SS & MS & F & P \\
\hline Between Groups & 4 & 0.292 & 0.0729 & 34.943 & $<0.001$ \\
\hline Residual & 15 & 0.0313 & 0.00209 & & \\
\hline Total & 19 & 0.323 & & & \\
\hline
\end{tabular}

The differences in the mean values among the treatment groups are greater than would be expected by chance; there is a statistically significant difference $(\mathrm{P}=<0.001)$.

Power of performed test with alpha $=0.050: 1.000$

All pairwise multiple comparison procedures (Tukey Test):

Comparisons for factor:

\begin{tabular}{c|c|c|c|c|c}
\hline Comparison & Diff of Means & $\mathbf{p}$ & $\mathbf{q}$ & $\mathbf{P}$ & $\mathbf{P}<\mathbf{0 . 0 5 0}$ \\
\hline 0 vs. 0.5 & 0.350 & 5 & 15.323 & $<0.001$ & Yes \\
\hline 0 vs. 0.1 & 0.270 & 5 & 11.821 & $<0.001$ & Yes \\
\hline 0 vs. 0.05 & 0.190 & 5 & 8.318 & $<0.001$ & Yes \\
\hline 0 vs. 0.01 & 0.120 & 5 & 5.254 & 0.015 & Yes \\
\hline
\end{tabular}




\begin{tabular}{c|c|c|c|c|c}
\hline 0.01 vs. 0.5 & 0.230 & 5 & 10.070 & $<0.001$ & Yes \\
\hline 0.01 vs. 0.1 & 0.150 & 5 & 6.567 & 0.003 & Yes \\
\hline 0.01 vs. 0.05 & 0.0700 & 5 & 3.065 & 0.244 & No \\
\hline 0.05 vs. 0.5 & 0.160 & 5 & 7.005 & 0.001 & Yes \\
\hline 0.05 vs. 0.1 & 0.0800 & 5 & 3.503 & 0.149 & No \\
\hline 0.1 vs. 0.5 & 0.0800 & 5 & 3.503 & 0.149 & No \\
\hline
\end{tabular}

One way analysis of variance

Data source: Grain_6.6

\begin{tabular}{c|c|c|c|c|c}
\hline Group Name & $\mathbf{N}$ & Missing & Mean & Std Dev & SEM \\
\hline 0 & 4 & 0 & 3.790 & 0.0490 & 0.0245 \\
\hline 0.01 & 4 & 0 & 3.960 & 0.0390 & 0.0195 \\
\hline 0.05 & 4 & 0 & 4.140 & 0.0440 & 0.0220 \\
\hline 0.1 & 4 & 0 & 3.870 & 0.0520 & 0.0260 \\
\hline 0.5 & 4 & 0 & 3.840 & 0.0340 & 0.0170 \\
\hline
\end{tabular}

\begin{tabular}{c|c|c|c|c|c}
\hline Source of Variation & DF & SS & MS & F & P \\
\hline Between Groups & 4 & 0.303 & 0.0758 & 39.000 & $<0.001$ \\
\hline Residual & 15 & 0.0292 & 0.00194 & & \\
\hline Total & 19 & 0.332 & & & \\
\hline
\end{tabular}

The differences in the mean values among the treatment groups are greater than would be expected by chance; there is a statistically significant difference $(\mathrm{P}=<0.001)$.

Power of performed test with alpha $=0.050: 1.000$

All pairwise multiple comparison procedures (Tukey Test):

Comparisons for factor:

\begin{tabular}{c|c|c|c|c|c}
\hline Comparison & Diff of Means & $\mathbf{p}$ & $\mathbf{q}$ & $\mathbf{P}$ & $\mathbf{P}<\mathbf{0 . 0 5 0}$ \\
\hline 0.05 vs. 0 & 0.350 & 5 & 15.878 & $<0.001$ & Yes \\
\hline 0.05 vs. 0.5 & 0.300 & 5 & 13.610 & $<0.001$ & Yes \\
\hline 0.05 vs. 0.1 & 0.270 & 5 & 12.249 & $<0.001$ & Yes \\
\hline 0.05 vs. 0.01 & 0.180 & 5 & 8.166 & $<0.001$ & Yes \\
\hline 0.01 vs. 0 & 0.170 & 5 & 7.712 & $<0.001$ & Yes \\
\hline 0.01 vs. 0.5 & 0.120 & 5 & 5.444 & 0.012 & Yes \\
\hline 0.01 vs. 0.1 & 0.0900 & 5 & 4.083 & 0.072 & No \\
\hline 0.1 vs. 0 & 0.0800 & 5 & 3.629 & 0.128 & No \\
\hline 0.1 vs. 0.5 & 0.0300 & 5 & 1.361 & 0.868 & Do Not Test \\
\hline 0.5 vs. 0 & 0.0500 & 5 & 2.268 & 0.517 & Do Not Test \\
\hline
\end{tabular}

A result of "Do Not Test" occurs for a comparison when no significant difference is found between two means that enclose that comparison. For example, if you had four means sorted in order, and found no difference between means 4 vs. 2, then you would not test 4 vs. 3 and 3 vs. 2 , but still test 4 vs. 1 and 3 vs. 1 ( 4 vs. 3 and 3 vs. 2 are enclosed by 4 vs. 2: 432 1). Note that not testing the enclosed means is a 


$$
-2417 \text { - }
$$

procedural rule, and a result of Do Not Test should be treated as if there is no significant difference between the means, even though one may appear to exist.

\section{One way analysis of variance}

Data source: Total protein content

\begin{tabular}{c|c|c|c|c|c}
\hline Group Name & $\mathbf{N}$ & Missing & Mean & Std Dev & SEM \\
\hline 0 & 4 & 0 & 12.400 & 0.400 & 0.200 \\
\hline 0.01 & 4 & 0 & 13.900 & 0.600 & 0.300 \\
\hline 0.05 & 4 & 0 & 14.300 & 0.300 & 0.150 \\
\hline 0.1 & 4 & 0 & 13.800 & 0.300 & 0.150 \\
\hline 0.5 & 4 & 0 & 13.600 & 0.500 & 0.250 \\
\hline
\end{tabular}

\begin{tabular}{c|c|c|c|c|c}
\hline Source of Variation & DF & SS & MS & F & P \\
\hline Between Groups & 4 & 8.240 & 2.060 & 10.842 & $<0.001$ \\
\hline Residual & 15 & 2.850 & 0.190 & & \\
\hline Total & 19 & 11.090 & & & \\
\hline
\end{tabular}

The differences in the mean values among the treatment groups are greater than would be expected by chance; there is a statistically significant difference $(\mathrm{P}=<0.001)$.

Power of performed test with alpha $=0.050: 0.997$

All pairwise multiple comparison procedures (Tukey Test):

Comparisons for factor:

\begin{tabular}{c|c|c|c|c|c}
\hline Comparison & Diff of Means & $\mathbf{p}$ & $\mathbf{q}$ & $\mathbf{P}$ & P<0.050 \\
\hline 0.05 vs. 0 & 1.900 & 5 & 8.718 & $<0.001$ & Yes \\
\hline 0.05 vs. 0.5 & 0.700 & 5 & 3.212 & 0.208 & No \\
\hline 0.05 vs. 0.1 & 0.500 & 5 & 2.294 & 0.507 & Do Not Test \\
\hline 0.05 vs. 0.01 & 0.400 & 5 & 1.835 & 0.697 & Do Not Test \\
\hline 0.01 vs. 0 & 1.500 & 5 & 6.882 & 0.002 & Yes \\
\hline 0.01 vs. 0.5 & 0.300 & 5 & 1.376 & 0.863 & Do Not Test \\
\hline 0.01 vs. 0.1 & 0.1000 & 5 & 0.459 & 0.997 & Do Not Test \\
\hline 0.1 vs. 0 & 1.400 & 5 & 6.424 & 0.003 & Yes \\
\hline 0.1 vs. 0.5 & 0.200 & 5 & 0.918 & 0.964 & Do Not Test \\
\hline 0.5 vs. 0 & 1.200 & 5 & 5.506 & 0.011 & Yes
\end{tabular}

A result of "Do Not Test" occurs for a comparison when no significant difference is found between two means that enclose that comparison. For example, if you had four means sorted in order, and found no difference between means 4 vs. 2, then you would not test 4 vs. 3 and 3 vs. 2 , but still test 4 vs. 1 and 3 vs. 1 ( 4 vs. 3 and 3 vs. 2 are enclosed by 4 vs. 2: 432 1). Note that not testing the enclosed means is a procedural rule, and a result of Do Not Test should be treated as if there is no significant difference between the means, even though one may appear to exist. 
One way analysis of variance

Data source: Albumins

\begin{tabular}{c|c|c|c|c|c}
\hline Group Name & $\mathbf{N}$ & Missing & Mean & Std Dev & SEM \\
\hline 0 & 4 & 0 & 24.700 & 0.700 & 0.350 \\
\hline 0.01 & 4 & 0 & 25.300 & 0.400 & 0.200 \\
\hline 0.05 & 4 & 0 & 23.900 & 0.900 & 0.450 \\
\hline 0.1 & 4 & 0 & 21.800 & 0.600 & 0.300 \\
\hline 0.5 & 4 & 0 & 20.100 & 0.400 & 0.200 \\
\hline
\end{tabular}

\begin{tabular}{c|c|c|c|c|c}
\hline Source of Variation & DF & SS & MS & F & P \\
\hline Between Groups & 4 & 74.848 & 18.712 & 47.253 & $<0.001$ \\
\hline Residual & 15 & 5.940 & 0.396 & & \\
\hline Total & 19 & 80.788 & & & \\
\hline
\end{tabular}

The differences in the mean values among the treatment groups are greater than would be expected by chance; there is a statistically significant difference $(\mathrm{P}=<0.001)$.

Power of performed test with alpha $=0.050: 1.000$

All pairwise multiple comparison procedures (Tukey Test):

Comparisons for factor:

\begin{tabular}{c|c|c|c|c|c}
\hline Comparison & Diff of Means & $\mathbf{p}$ & $\mathbf{q}$ & $\mathbf{P}$ & $\mathbf{P}<\mathbf{0 . 0 5 0}$ \\
\hline 0.01 vs. 0.5 & 5.200 & 5 & 16.527 & $<0.001$ & Yes \\
\hline 0.01 vs. 0.1 & 3.500 & 5 & 11.124 & $<0.001$ & Yes \\
\hline 0.01 vs. 0.05 & 1.400 & 5 & 4.449 & 0.045 & Yes \\
\hline 0.01 vs. 0 & 0.600 & 5 & 1.907 & 0.667 & No \\
\hline 0 vs. 0.5 & 4.600 & 5 & 14.620 & $<0.001$ & Yes \\
\hline 0 vs. 0.1 & 2.900 & 5 & 9.217 & $<0.001$ & Yes \\
\hline 0 vs. 0.05 & 0.800 & 5 & 2.543 & 0.410 & No \\
\hline 0.05 vs. 0.5 & 3.800 & 5 & 12.077 & $<0.001$ & Yes \\
\hline 0.05 vs. 0.1 & 2.100 & 5 & 6.674 & 0.002 & Yes \\
\hline 0.1 vs. 0.5 & 1.700 & 5 & 5.403 & 0.012 & Yes \\
\hline
\end{tabular}

One way analysis of variance

Data source: Globulins

\begin{tabular}{c|c|c|c|c|c}
\hline Group Name & $\mathbf{N}$ & Missing & Mean & Std Dev & SEM \\
\hline 0 & 4 & 0 & 19.200 & 0.200 & 0.1000 \\
\hline 0.01 & 4 & 0 & 19.800 & 0.600 & 0.300 \\
\hline 0.05 & 4 & 0 & 21.600 & 0.600 & 0.300 \\
\hline 0.1 & 4 & 0 & 23.400 & 0.400 & 0.200 \\
\hline 0.5 & 4 & 0 & 25.900 & 0.800 & 0.400 \\
\hline
\end{tabular}




\begin{tabular}{c|c|c|c|c|c}
\hline Source of Variation & DF & SS & MS & F & P \\
\hline Between Groups & 4 & 120.032 & 30.008 & 96.179 & $<0.001$ \\
\hline Residual & 15 & 4.680 & 0.312 & & \\
\hline Total & 19 & 124.712 & & & \\
\hline
\end{tabular}

The differences in the mean values among the treatment groups are greater than would be expected by chance; there is a statistically significant difference $(\mathrm{P}=<0.001)$.

Power of performed test with alpha $=0.050: 1.000$

All pairwise multiple comparison procedures (Tukey Test):

Comparisons for factor:

\begin{tabular}{c|c|c|c|c|c}
\hline Comparison & Diff of Means & $\mathbf{p}$ & $\mathbf{q}$ & $\mathbf{P}$ & $\mathbf{P}<\mathbf{0 . 0 5 0}$ \\
\hline 0.5 vs. 0 & 6.700 & 5 & 23.990 & $<0.001$ & Yes \\
\hline 0.5 vs. 0.01 & 6.100 & 5 & 21.842 & $<0.001$ & Yes \\
\hline 0.5 vs. 0.05 & 4.300 & 5 & 15.396 & $<0.001$ & Yes \\
\hline 0.05 vs. 0.1 & 2.500 & 5 & 8.951 & $<0.001$ & Yes \\
\hline 0.1 vs. 0 & 4.200 & 5 & 15.038 & $<0.001$ & Yes \\
\hline 0.1 vs. 0.01 & 3.600 & 5 & 12.890 & $<0.001$ & Yes \\
\hline 0.1 vs. 0.05 & 1.800 & 5 & 6.445 & 0.003 & Yes \\
\hline 0.05 vs. 0 & 2.400 & 5 & 8.593 & $<0.001$ & Yes \\
\hline 0.05 vs. 0.01 & 1.800 & 5 & 6.445 & 0.003 & Yes \\
\hline 0.01 vs. 0 & 0.600 & 5 & 2.148 & 0.567 & No
\end{tabular}

One way analysis of variance

Data source: Prolamins

\begin{tabular}{c|c|c|c|c|c}
\hline Group Name & N & Missing & Mean & Std Dev & SEM \\
\hline 0 & 4 & 0 & 25.400 & 0.400 & 0.200 \\
\hline 0.01 & 4 & 0 & 24.700 & 0.700 & 0.350 \\
\hline 0.05 & 4 & 0 & 25.100 & 0.800 & 0.400 \\
\hline 0.1 & 4 & 0 & 23.400 & 0.600 & 0.300 \\
\hline 0.5 & 4 & 0 & 24.200 & 0.900 & 0.450 \\
\hline
\end{tabular}

\begin{tabular}{c|c|c|c|c|c}
\hline Source of Variation & DF & SS & MS & F & P \\
\hline Between Groups & 4 & 9.968 & 2.492 & 5.065 & 0.009 \\
\hline Residual & 15 & 7.380 & 0.492 & & \\
\hline Total & 19 & 17.348 & & & \\
\hline
\end{tabular}

The differences in the mean values among the treatment groups are greater than would be expected by chance; there is a statistically significant difference $(\mathrm{P}=0.009)$.

Power of performed test with alpha $=0.050: 0.802$

All pairwise multiple comparison procedures (Tukey Test):

Comparisons for factor: 


\begin{tabular}{c|c|c|c|c|c}
\hline Comparison & Diff of Means & $\mathbf{p}$ & $\mathbf{q}$ & $\mathbf{P}$ & $\mathbf{P}<\mathbf{0 . 0 5 0}$ \\
\hline 0 vs. 0.1 & 2.000 & 5 & 5.703 & 0.008 & Yes \\
\hline 0 vs. 0.5 & 1.200 & 5 & 3.422 & 0.163 & No \\
\hline 0 vs. 0.01 & 0.700 & 5 & 1.996 & 0.630 & Do Not Test \\
\hline 0 vs. 0.05 & 0.300 & 5 & 0.855 & 0.972 & Do Not Test \\
\hline 0.05 vs. 0.1 & 1.700 & 5 & 4.847 & 0.026 & Yes \\
\hline 0.05 vs. 0.5 & 0.900 & 5 & 2.566 & 0.401 & Do Not Test \\
\hline 0.05 vs. 0.01 & 0.400 & 5 & 1.141 & 0.925 & Do Not Test \\
\hline 0.01 vs. 0.1 & 1.300 & 5 & 3.707 & 0.116 & No \\
\hline 0.01 vs. 0.5 & 0.500 & 5 & 1.426 & 0.848 & Do Not Test \\
\hline 0.5 vs. 0.1 & 0.800 & 5 & 2.281 & 0.512 & Do Not Test \\
\hline
\end{tabular}

A result of "Do Not Test" occurs for a comparison when no significant difference is found between two means that enclose that comparison. For example, if you had four means sorted in order, and found no difference between means 4 vs. 2, then you would not test 4 vs. 3 and 3 vs. 2, but still test 4 vs. 1 and 3 vs. 1 ( 4 vs. 3 and 3 vs. 2 are enclosed by 4 vs. 2: 432 1). Note that not testing the enclosed means is a procedural rule, and a result of Do Not Test should be treated as if there is no significant difference between the means, even though one may appear to exist.

One Way Analysis of Variance

Data source: Glutelins

\begin{tabular}{c|c|c|c|c|c}
\hline Group Name & $\mathbf{N}$ & Missing & Mean & Std Dev & SEM \\
\hline 0 & 4 & 0 & 16.500 & 0.200 & 0.1000 \\
\hline 0.01 & 4 & 0 & 17.800 & 0.600 & 0.300 \\
\hline 0.05 & 4 & 0 & 18.200 & 0.400 & 0.200 \\
\hline 0.1 & 4 & 0 & 19.700 & 0.800 & 0.400 \\
\hline 0.5 & 4 & 0 & 23.400 & 0.700 & 0.350 \\
\hline
\end{tabular}

\begin{tabular}{c|c|c|c|c|c}
\hline Source of Variation & DF & SS & MS & F & P \\
\hline Between Groups & 4 & 112.432 & 28.108 & 83.160 & $<0.001$ \\
\hline Residual & 15 & 5.070 & 0.338 & & \\
\hline Total & 19 & 117.502 & & & \\
\hline
\end{tabular}

The differences in the mean values among the treatment groups are greater than would be expected by chance; there is a statistically significant difference $(\mathrm{P}=<0.001)$.

Power of performed test with alpha $=0.050: 1.000$

All pairwise multiple comparison procedures (Tukey Test):

Comparisons for factor:

\begin{tabular}{c|c|c|c|c|c}
\hline Comparison & Diff of Means & $\mathbf{p}$ & $\mathbf{q}$ & $\mathbf{P}$ & $\mathbf{P}<\mathbf{0 . 0 5 0}$ \\
\hline 0.5 vs. 0 & 6.900 & 5 & 23.737 & $<0.001$ & Yes \\
\hline 0.5 vs. 0.01 & 5.600 & 5 & 19.265 & $<0.001$ & Yes \\
\hline 0.5 vs. 0.05 & 5.200 & 5 & 17.889 & $<0.001$ & Yes \\
\hline 0.5 vs. 0.1 & 3.700 & 5 & 12.728 & $<0.001$ & Yes \\
\hline
\end{tabular}




\begin{tabular}{c|c|c|c|c|c}
\hline 0.1 vs. 0 & 3.200 & 5 & 11.008 & $<0.001$ & Yes \\
\hline 0.1 vs. 0.01 & 1.900 & 5 & 6.536 & 0.003 & Yes \\
\hline 0.1 vs. 0.05 & 1.500 & 5 & 5.160 & 0.017 & Yes \\
\hline 0.05 vs. 0 & 1.700 & 5 & 5.848 & 0.007 & Yes \\
\hline 0.05 vs. 0.01 & 0.400 & 5 & 1.376 & 0.863 & No \\
\hline 0.01 vs. 0 & 1.300 & 5 & 4.472 & 0.044 & Yes \\
\hline
\end{tabular}

